U.S. DEPARTMENT OF THE INTERIOR

U.S. GEOLOGICAL SURVEY

\title{
Composition of waters from the Research Drill Hole at the summit of Kilauea Volcano, Hawaii: 1973-1991
}

by

\author{
Robert I. Tilling1 \\ and \\ Blair F. Jones 2
}

\section{Open-File Report $\mathbf{9 5 - 5 3 2}$}

This report is preliminary and has not been reviewed for conformity with U.S. Geological Survey editorial standards or with the North American Stratigraphic Code. Any use of trade, product, or firm names is for descriptive purposes only and does not imply endorsement by the U.S. Government. 


\section{ABSTRACT}

Over a three-year period (September 1973-April 1976), water was sampled from a $1262 \mathrm{~m}$-deep research borehole drilled to penetrate the hydrothermal convection cell above Kilauea's summit magma reservoir, the top of which lies 2-4 km below the surface. After a hiatus of 15 years, two additional samples were collected in August-September 1991. Nearly all of the samples were collected within about $30 \mathrm{~m}$ of the top of the water column ( $488 \mathrm{~m}$ below ground surface), most from the uppermost $2 \mathrm{~m}$; post-drilling attempts to collect deeper, hotter samples were unsuccessful. To allow dissipation of drilling-induced disturbance, sampling was not initiated until early September 1973, nearly two months after well completion. Chemical data indicate that the summit-borehole waters have a distinctive chemical signature-low proportion of chloride relative to other anions-when compared with thermal waters from Kilauea's lower east-rift zone as well as with nonthermal waters of the Hawaiian Islands.

The analytical data demonstrate both short-term (days to weeks) and longer term (months to years) temporal variations. A sample collected two days after $37 \mathrm{~cm}$ of rain had fallen in a three-day period showed significant dilution of nearly all ion concentrations, which then recovered to pre-heavy-rainfall levels within $<\sim 2.5$ months. Samples collected in the 1973-74 period are Na-sulfate-dominant, but samples collected after July, 1975 are $(\mathrm{Mg}+\mathrm{Ca})$ bicarbonate-dominant. This compositional shift is abrupt and associated with an increase in the partial pressure of $\mathrm{CO}_{2}\left(\mathrm{PCO}_{2}\right)$ accompanying the eruptive and intrusive activity on 31 December 1974, the most voluminous event affecting the southwest rift zone of Kilauea since 1919. Following the initial sharp increase, the $\mathrm{PCO}_{2}$ then decreased, approaching pre-eruption values with the sampling in April 1976.

Beginning in mid-1975, solute concentrations of the borehole waters decreased sharply, from about $45 \mathrm{meq} / \mathrm{L}$ to less than $25 \mathrm{meq} / \mathrm{L}$ in only 8 months. This rapid decline cannot be explained by dilution effects because rainfall during the period was not unusually high. The observed trend may simply reflect the decreasing availability of the easily leachable alkalis and $\mathrm{SO}_{4}$, which originated in sublimates and encrustations along fractures and in cavities. By 1991, total solute concentrations had decreased to $<17 \mathrm{meq} / \mathrm{L}$.

The overall chemistry of the summit-borehole waters is largely determined by weathering of host tholeiitic basalts on a geologic time scale. However, the temporal variations observed over the three-year sampling period reflect shorter term perturbations related to variations in rainfall/recharge, volcanic activity/degassing, and the availability of leachable materials along the water-flow path, which in turn is influenced by fracture processes associated with seismicity and deformation acting on the volcanic edifice. 


\section{INTRODUCTION}

Kilauea, on the Island of Hawaii (Fig. 1), is the one of the most active volcanoes in the world (Tilling and Dvorak, 1993). It and its much larger neighbor, Mauna Loa, are among the Earth's best examples of intraplate shield volcanoes, constructed by countless outpourings of fluid basaltic (tholeiitic) lavas that travel great distances from the eruptive vents.

\section{Volcanic setting}

According to the now generally accepted plate-tectonics theory, Hawaiian volcanism is attributed to magma generation and ascent as the Pacific lithospheric plate drifts over a fixed or, at least much slower moving, melting anomaly ("Hawaiian hot spot") in the asthenosphere (e.g., Wilson, 1963; Dalrymple and others, 1973; McDougall, 1979; Clague and Dalrymple, 1987, 1989). Progressive movement, first northerly then northwesterly, of the Pacific plate for more than 75 million years has left a $6,000-\mathrm{km}$-long trail of volcanoes-the Hawaiian Ridge-Emperor Seamounts-across the Pacific seafloor, as each volcano was successively severed from the magma-feeding "hot spot" and a new volcano grew over it. According to this model, the currently active Hawaiian volcanoesKilauea, Mauna Loa, and also perhaps Loihi, the submarine volcano about 30 miles off the south coast of Hawaii-are still tapping the "hot spot." Abundant studies have shown that all eruptions or intrusion at Kilauea, whether within the caldera or along its rift zones, are, fed by magma that pass through a shallow summit reservoir, the top of which lies $2-4 \mathrm{~km}$ beneath the surface. The current activity of Kilauea on its east rift zone (Fig. 1), which began in January 1983 and continues as of this writing (January 1995), constitutes the longest Hawaiian rift eruption in historical time (Wolfe, 1988; Moulds and others, 1990; Heliker and Wright, 1991; Mattox, 1993; GVN, 1994).

\section{Summary of drilling studies}

In February 1972, George V. Keller (Department of Geophysics, Colorado School of Mines) submitted a proposal to the National Science Foundation (NSF) to drill a research borehole to study the hydrothermal convection cell above the magma reservoir of Kilauea Volcano, Hawaii. This proposal was funded, and during the period 6 April-9 July 1973 a $1262-\mathrm{m}(4137-\mathrm{ft})$ deep hole $\left(19^{\circ} 23.7^{\prime} \mathrm{N}, 155^{\circ} 13.3^{\prime}\right)$ was drilled at the summit of

the volcano. The hole, at an elevation of $1103 \mathrm{~m}$ (derrick floor), is within the southwestern part of the discontinuous, concentric caldera fault zone, next to the uppermost part of Kilauea's southwest-rift zone (SWRZ) (Fig. 1). The siting of the borehole, $1.1 \mathrm{~km}$ south of Halemaumau Crater (Fig. 2), was determined by the spatial association of the following seismic and other geophysical manifestations (Keller and others, 1979): 1) loci of 


\section{0-m contour internal}

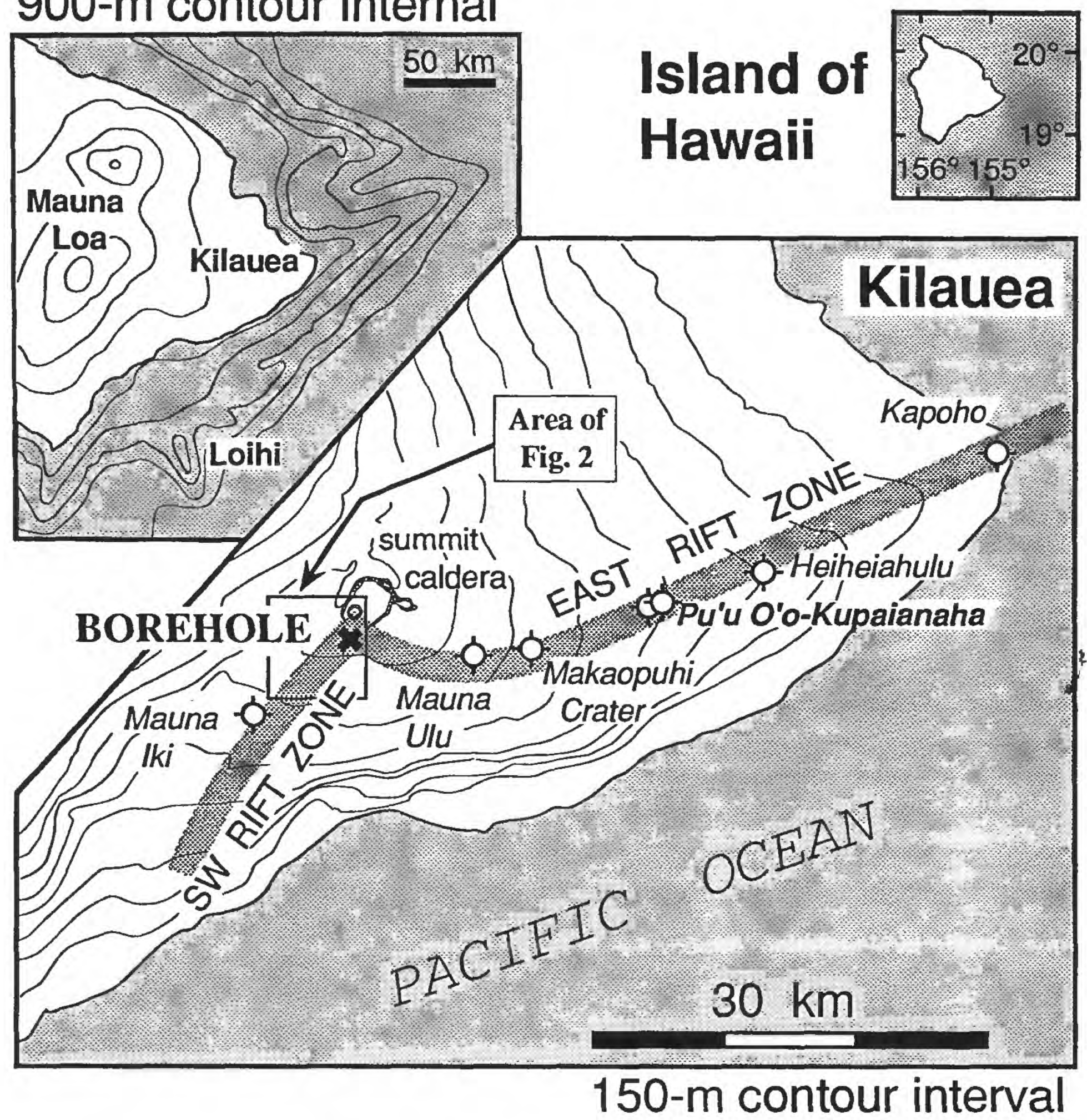

Fig. 1. Index map showing the Island of Hawaii, Kilauea and its rift zones, Mauna Loa, and the submarine active volcano Loihi (modified from Tilling and Dvorak, 1993); these three active volcanoes are inferred to overlie the contemporary "Hawaiian hot spot." Kilauea's continuing east-rift eruption, which began in January 1983, is centered at Pu'u O'o-Kupaianaha. The location of the research borehole at the summit of Kilauea is indicated by the $\mathbf{X}$ (see Fig. 2 for details). 


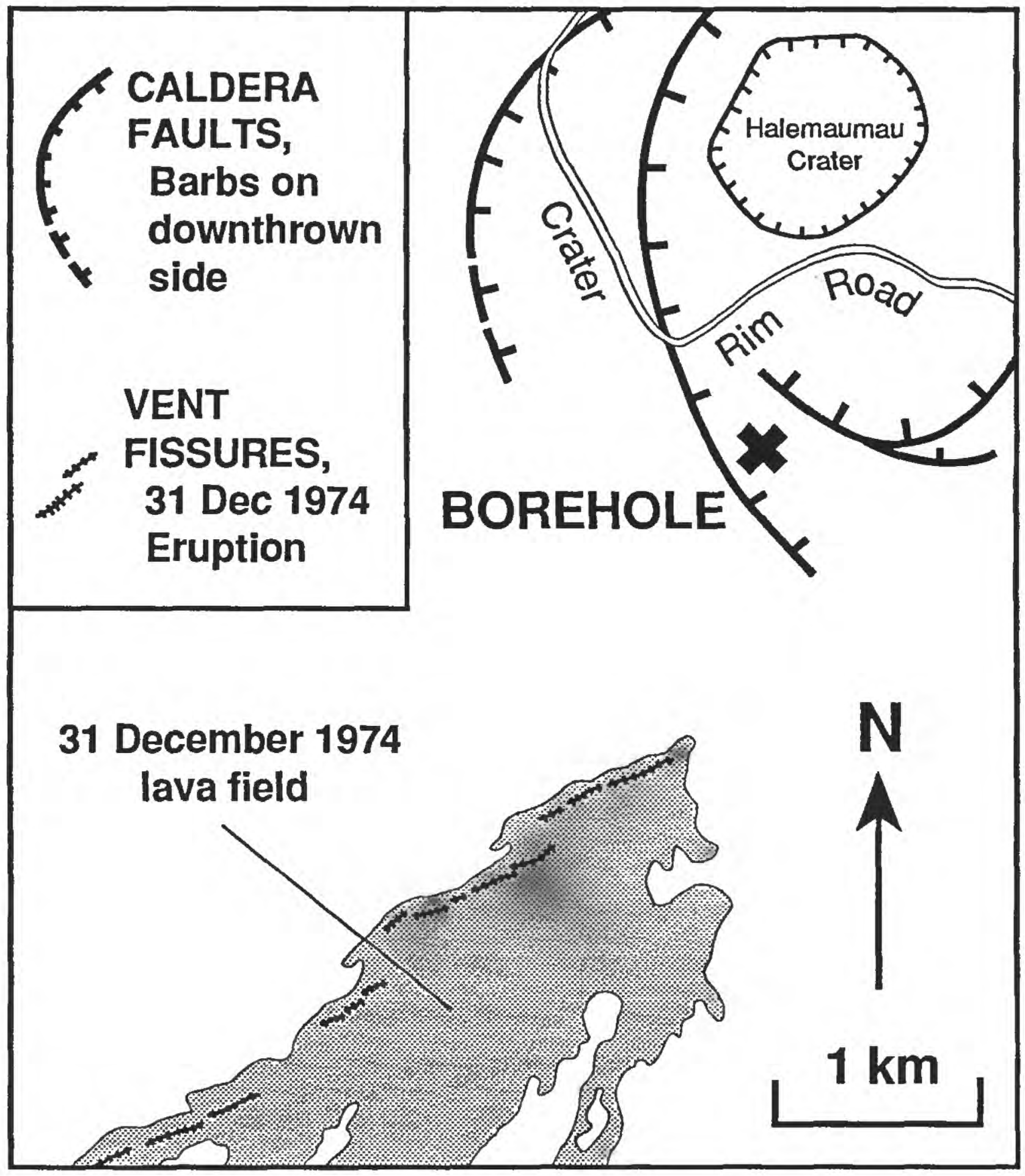

Fig. 2. Detailed location map of the summit borehole (X), relative to some major nested boundary faults of Kilauea caldera, Halemaumau Crater on the caldera floor, and the vent fissures of the 31 December 1974 eruption. 
frequent, intense shallow seismicity; 2) area commonly exhibiting maximum ground displacements (i.e., "inflation-deflation" centers); 3) zone of low resistivity ( $<20 \mathrm{ohm}$ meters) at shallow depth (Keller and others, 1979, Fig. 2); and 4) a positive self-potential anomaly of $\geq 0.5$ volts. Collectively, these manifestations provide evidence for, and constrain the location of, a shallow magma reservoir beneath Kilauea summit.

A standard rotary rig and water-base drilling mud (bentonite) were used to drill the hole; because of high permeability of some of the rock penetrated, circulation of drilling mud was never attained and neither were any cuttings returned (Zablocki and others, 1974). However, limited, but generally successful, coring of selected intervals throughout the entire depth of the hole was accomplished, and about 47 meters of core were recovered. Study of the cored samples showed them all to be flows or, less commonly, sills of olivine tholeiite, generally similar in composition to rocks of the Uwekahuna Bluff section of the Kilauea caldera wall studied by Casadevall and Dzurisin (1987). The top of standing water in the hole, assumed to mark the local water table, was at $488 \pm 2 \mathrm{~m}$ (below ground surface) during the 1973-1976 period; geophysical in-hole logging data indicated that the rocks were fully water saturated below the $\sim 488-\mathrm{m}$ level. Resistivity cross sections derived from Schlumberger-geoelectrical soundings illustrate that the water level within the drill hole coincides with the regional high-level water table (Jackson and Kauahikaua, 1990; Jackson and Lenat, 1989). Core samples above the water table are essentially unaltered, whereas samples below the water table contain varying amounts of alteration products (e.g., calcite, clay minerals, silica, zeolites) lining or filling vesicles and cracks. Reconnaissance study suggests that the degree of alteration increases slightly with depth (Keller and others, 1979). To date, however, no systematic petrologic-geochemical investigation has been made of the alteration minerals, nor of their host olivine tholeiites, encountered in the drill hole.

Temperaturre data obtained for the summit drill hole and their implications for Kilauea's geothermal system are not the focus of this study, but we summarize below the limited information available. Measurements made during and following the drilling indicate an upper convective regime and a lower conductive regime, reaching a maximum temperature of $137^{\circ} \mathrm{C}$ at hole bottom (Fig. 3A). The temperature reversal observed for the $725-950 \mathrm{~m}$ depth interval in the convective regime is interpreted to be due to cooling by descending cool waters, which in turn implies that the $500-725 \mathrm{~m}$ interval reflects an upwelling tongue of warm water (Keller and others, 1979). The conductive thermal gradient for the lowest 200 meters of the hole is about $370{ }^{\circ} \mathrm{C} / \mathrm{km}$, which, if persists or increases with depth, would yield magma temperatures at a depth of $\sim 4 \mathrm{~km}$, within the 2-4 $\mathrm{km}$ depth interval indicated for the top of Kilauea's magma reservoir by seismic and 


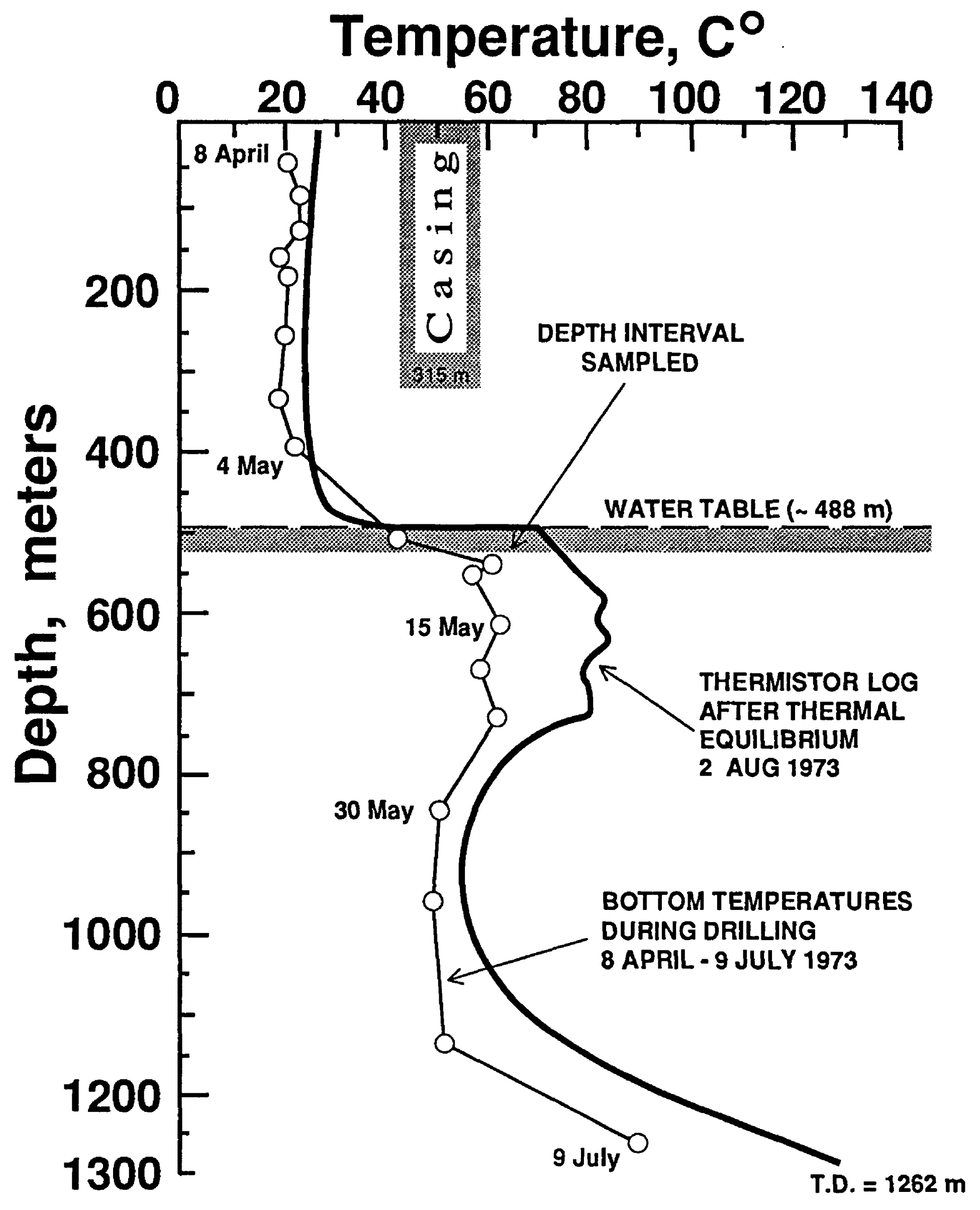

Fig. 3A. Temperature profiles for the summit borehole measured in 1973 (modified from Zablocki and others, 1974, Fig. 3); $35.6 \mathrm{~cm}$-diameter casing was installed down to a depth of $315 \mathrm{~m}$ (Keller, 1974). The profile for 2 August was the last of a dozen continuous temperature logs run between 12 July and 23 August to reach bottom (Fig. 3B). All but two of the samples analyzed in this study were collected from the horizon about $2 \mathrm{~m}$ below the water table (see text). 
geodetic data (Zablocki and others, 1974; Keller and others, 1979). The main mass of the magma reservoir is located between 4 - $7 \mathrm{~km}$ (Kauahikaua, 1993; Rowan and Clayton, 1993; Tilling and Dvorak, 1993). The Measurements also indicate that by early August 1973-about 24 days after cessation of drilling ( 9 July)-temperatures in the hole had stabilized (Fig. 3B; Keller and others, 1979, Fig. 15), suggesting a close approach to thermal equilibrium after drilling disturbance. Presently available temperature data are inadequate to indicate the presence or lack of a deeper, perhaps hotter zone of hydrothermal convection below the conductive regime (R.O. Fournier, 1993, written communication).

Additional preliminary results of the drilling and related studies are given in the following works and/or pertinent references contained therein: Murray (1974), Keller (1974), Keller and others (1974a,b; 1976; 1979), Zablocki and others (1976), and McMurtry and others (1977). Staff members of the U.S. Geological Survey's (USGS) Hawaiian Volcano Observatory worked collaboratively with investigators from the Colorado School Mines during and following the drilling project. Over a three-year period, beginning in September 1973 (a month after temperature stabilization in the hole), 15 water samples were collected (all but two by the USGS) from the borehole for chemical and isotopic analysis. Sampling was terminated in mid-1976 but resumed in summer of 1991 as part of a project to acquire additional data preparatory to a new assessment of the geothermal resources of the Island of Hawaii.

Purpose and scope of present study

Although unrelated to the Colorado School of Mines 1972 proposal for drilling at Kilauea's summit, the Hawaii Geothermal Project, under the auspices of the University of Hawaii (Honolulu), was launched in 1972 to develop geothermal power on the Island of Hawaii. After preliminary geologic and geophysical studies to select a drill site, an 1,996m-deep well (HGP-A) in Kilauea's lower east-rift zone (LERZ) was completed in April 1976 (Shupe and others, 1978). A three mega-watt wellhead generator was installed at this site in 1981 and operated for eight years before it was shut down in December 1989. Since the early 1980s, interest in geothermal studies has remained strong, and a number of privately financed deep exploration wells and publicly funded scientific observation holes have been drilled in the LERZ (Thomas, 1987; Thomas and others, 1990; Olson and others, 1990; Olson and Deymonaz, 1992; Kauahikaua, 1993).

Given this continuing scientific and commercial interest in geothermal systems in Hawaii, it seems important to make better known a unique set of time-series data on the composition of water in the hydrothermal system enveloping Kilauea's summit magma reservoir. This reservoir is the ultimate source of magma intruded into the east rift zone 


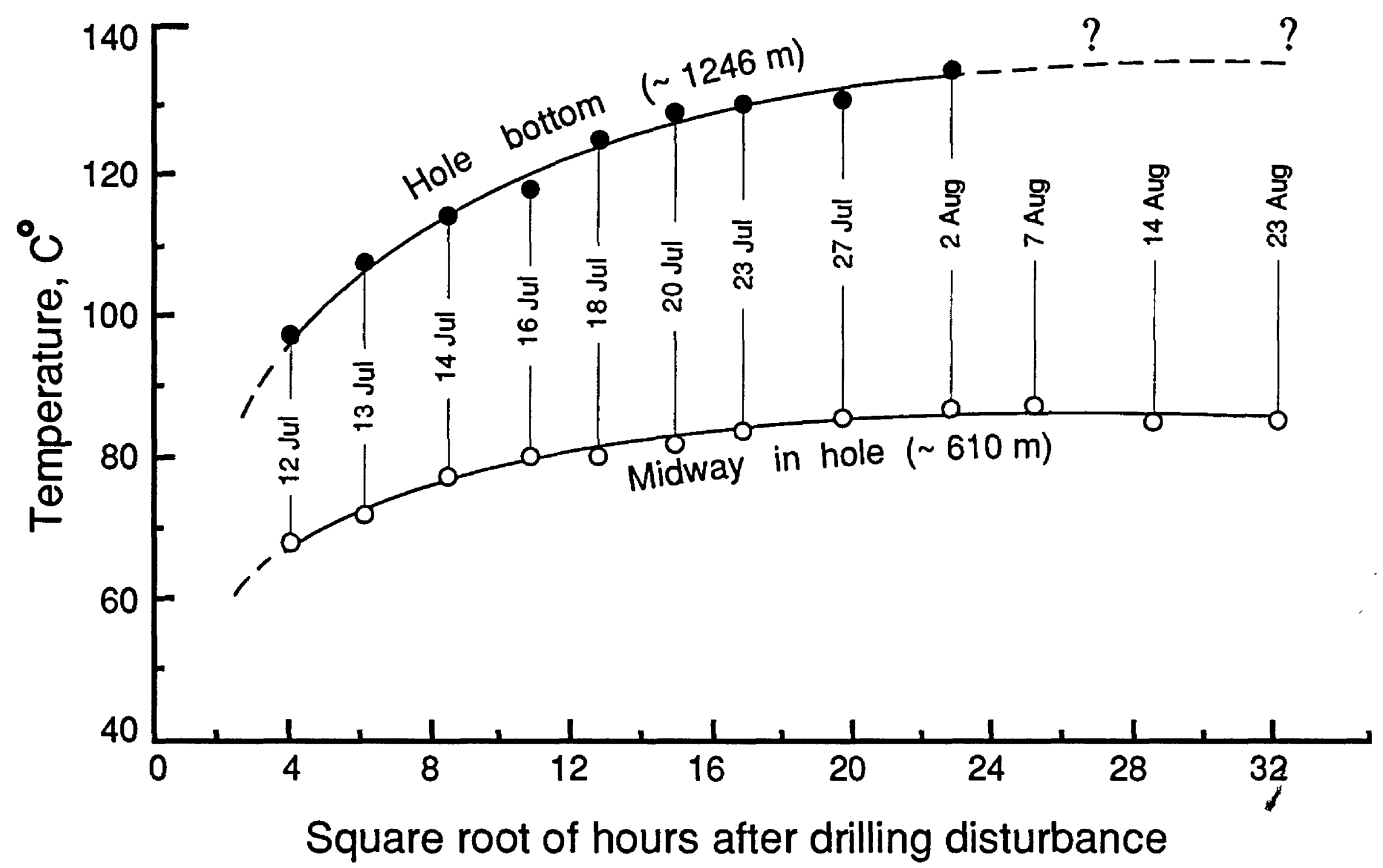

Fig. 3B. Plot of temperature, measured at bottom and midway of the summit borehole, against the square root of hours after drilling disturbance. Post-drilling blockage due to the settling and stiffening of the drill mud left within the hole prevented the full penetration of the thermistorlogging instrument after 2 August 1973. Both curves, however, indicate close approach to thermal equilibrium by mid-August. [Data source: Murray, 1974; Keller, 1974; Tilling, unpublished data]. 
that provides the heat source(s) for the geothermal system(s) there currently under intensive study. Bottom temperatures in the range of $200-362^{\circ} \mathrm{C}$ have been encountered in six of the nine deep holes drilled into LERZ to date (Kauahikaua, 1993, Table 1).

To date, the summit borehole provides the only direct probe into the hydrothermal system associated with Kilauea's central magma reservoir. The purpose of this study is two-fold: (1) to analyze the recently released compositional data (Tilling and Jones, 1991a) on water above Kilauea's summit reservoir and other Hawaiian water samples collected in connection with the borehole study; and (2) to more fully consider a preliminary interpretation of the observed temporal variations in composition of the summit-borehole waters within a context of Kilauea's eruptive dynamics (Tilling and Jones, 1990, 1991b).

Unfortunately, no data exist for the summit-borehole waters during the period May 1976-July 1991. Thus, our focus is primarily on the time-series data for the period 19731976, but relevant information on the two samples collected in 1991 is considered as appropriate in our interpretation.

\section{SAMPLING AND TEMPERATURE MEASUREMENT}

In-hole thermistor temperature logs (Fig. 3) suggested that drilling-induced thermal disturbance of the summit borehole had largely, or possibly completely, dissipated by early August 1973, about a month after cessation of drilling on 9 July 1973. However, to allow additional time for more complete elimination of drilling effects, water sampling was not initiated until 4 September 1973, nearly two months after well completion. Except for two samples, all the waters from the borehole (Table 1) were collected by means of a cylindrical steel bucket $(\sim 8 \mathrm{~cm} \mathrm{I.D.,} \sim 60 \mathrm{~cm}$ length) attached to a steel cable of known length and marked at known depth intervals. The sampling bucket was lowered and raised manually by means of a sheave positioned near the borehole opening; Figure 4 shows a typical sampling configuration. All but two of the samples we analyzed were taken from a horizon about $2 \mathrm{~m}$ below the top of the water column (the local water table at $\sim 488 \mathrm{~m}$ ). Two samples-numbers 50 and KBW-8 (Table 1)-were obtained from a level about $30.5 \mathrm{~m} \mathrm{(}$ $100 \mathrm{ft}$ ) below the water table using a thief sampler; attempts to collect deeper and hotter samples failed because of mechanical difficulties. Borehole temperatures in a $4.5-\mathrm{m}$ interval bracketing the water table, were measured by maximum-reading thermometers affixed to the cable and bucket (as shown in Figure 4) and are in accord with equilibrium in-hole thermistor temperature logs (Fig. 3). The temperatures for the 1973-1976 samples $\left(70-83^{\circ} \mathrm{C}\right)$ given in Appendix are the higher of readings registered by the two thermometers located immediately above and below the sampling bucket (Fig. 4). 


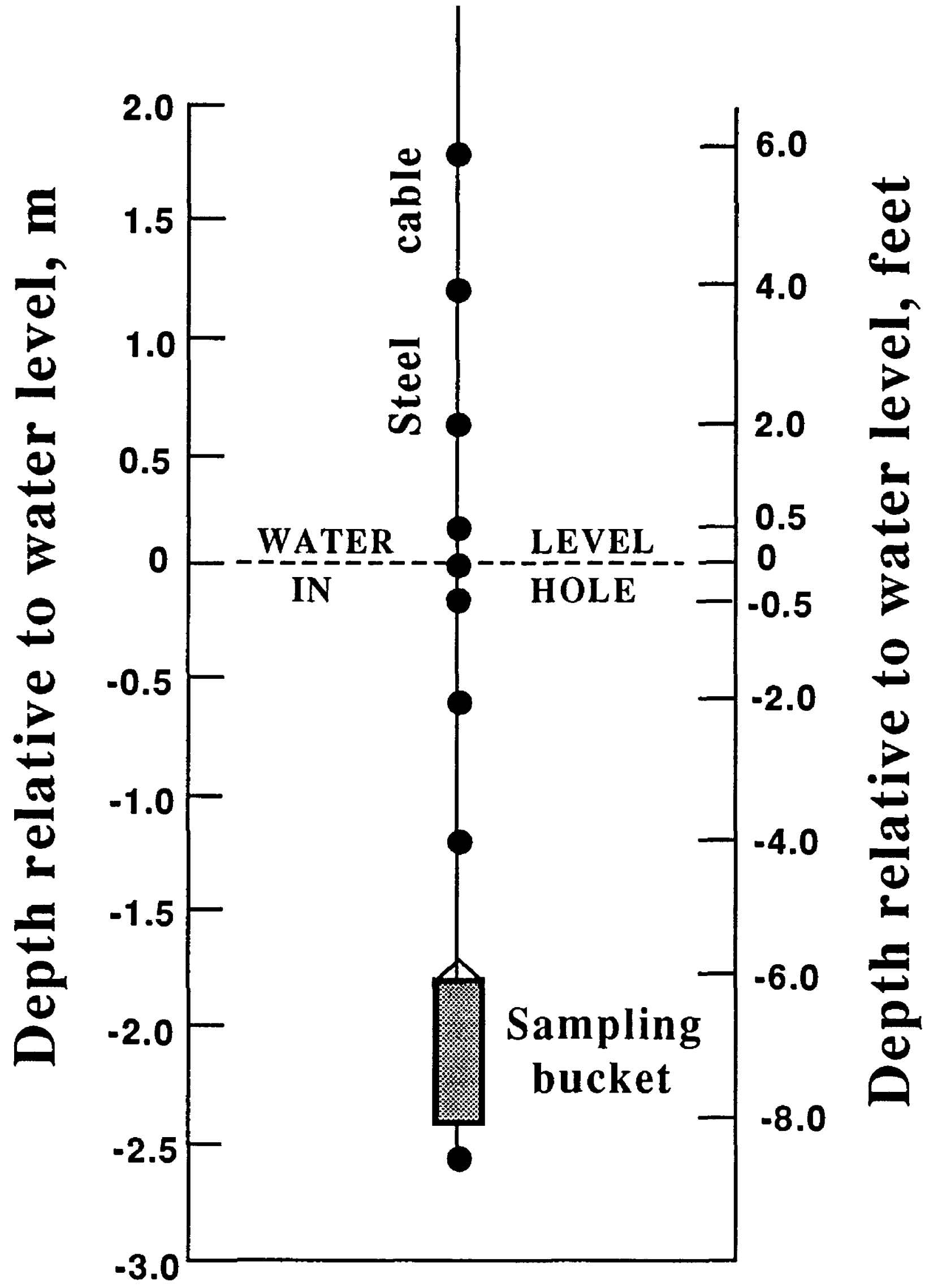

Fig. 4. Diagram showing system for sampling and temperature measurement used in the collection of waters from the summit borehole (modified from Tilling and Jones, 1991a, Fig. 2). The solid circles indicate the locations of maximum thermometers along the sampling cable. 
Several deep (946-1139 m) samples were obtained within two days (10-11 July 1973) after cessation of drilling by a Schlumberger "sidewall formation tester" (Keller, 1974), and partial chemical analyses ( $\mathrm{Ca}, \mathrm{Mg}, \mathrm{Na}, \mathrm{K}, \mathrm{Cl}, \mathrm{F}, \mathrm{Co}$ ) are available for some of them (Tilling and Jones, 1991a, Table 8). Though not measured, the temperatures for these samples probably would have been in the range of $60-75^{\circ} \mathrm{C}$., as constrained by the in-hole temperature data (Fig. 3A). While some constituents analyzed ( $\mathrm{Ca}, \mathrm{Mg}, \mathrm{Na}, \mathrm{K}$, and $\mathrm{Cl}$ ) for formation fluids tend to increase with depth, the range of variation for these elements (except $\mathrm{Mg}$ ) is within the range observed for the entire suite of samples subsequently collected, beginning on 4 September 1973 . This apparent variation with depth may simply reflect dilution by drilling fluids or higher level recharge. In any case, the compositions of these deep samples do not show any systematic differences from those for samples at the top of the water column $\left(70-83{ }^{\circ} \mathrm{C}\right.$ measured) given in Table 1; unfortunately, the partial analyses of these few deep, but poorly controlled, samples (representing a single point in time) contribute little to the understanding of the temporal compositional variations of shallower waters sampled subsequently.

After of a hiatus of 15 years, two waters samples were collected from the borehole in August and September of 1991 (GT24SI91 and GT35SI91) -by Martha Scholl, Larry Mastin, and Steve E. Ingebritsen (USGS, Menlo Park)-using methods similar to those described above. However, the top of the water column was encountered at about $466 \mathrm{~m}$ below ground surface, rather than $\sim 488 \mathrm{~m}$ (Appendix) for the earlier samples, indicating an apparent rise in water level of $\sim 20 \mathrm{~m}$. Also, the temperature of the August 1991 sample $\left(35.7^{\circ} \mathrm{C}\right)$ was significantly lower than the $70-83^{\circ} \mathrm{C}$ temperature range observed for the 1973-1976 samples (Appendix). This decrease in temperature may reflect the cooling of the rising water as it encountered colder rock (Figs 3 and 4). The reason for the rise of water in the well is not understood. The rise in water level cannot be explained by ground deformation of the volcano, because geodetic measurements (unpublished data, Hawaiian Volcano Observatory) indicate that the net subsidence at borehole site over the 1976-1991 interval amounted only to about $1 \mathrm{~m}$. A possible mechanism requires a heating of the deeper hydrothermal convection cell since 1976, and the resulting decrease in water density would allow a higher water column. This explanation, while permissible, cannot be tested however, because no deep temperature profiles could be obtained after 23 August 1973 (Fig. 3B) because of blockage in the hole. Another contributing factor may be the slow settling of the drilling mud from the water; as the mud settles out, the remaining fluid becomes less dense and should attain a higher level in the well to balance the pore-fluid pressure in the surrounding rock. 
To place the study of the summit-borehole waters in a regional context, we also analyzed thermal and non-thermal water samples collected at various other sites on Kilauea and neighboring Mauna Loa Volcano (Fig. 5). These samples include rainfall, perched water in shallow boreholes $(<111 \mathrm{~m})$, water from drilled wells, water from intermittent streams, and water ponded in a permafrost crack (see Table 2). Descriptive information about the samples analyzed for this study (Tables 1 and 2) are given in the Appendix.

\section{ANALYTICAL METHODS}

Chemical analyses of the water samples collected after well completion (Tables 1 and 2) were made at laboratories of the Water Resources Division (WRD), U.S. Geological Survey, located at Arlington and (later) Reston, Virginia (1973-1976 samples), or at Menlo Park (1991 samples), California, using techniques similar to those described in Skougstad and others (1979). Because the borehole was not flushed clean after cessation of drilling, all water samples collected during 1973-1976 from the summit borehole (Table 1) contained varying amounts of suspended drilling mud, which had to be filtered out prior to analysis; the August 1991 sample also contained mud but the September 1991 sample was essentially mud-free. Hydrogen and oxygen isotopic compositions of the 1973-76 samples were determined in WRD's stable-isotope laboratory (Arlington, Virginia), supervised by Tyler Coplen, by analytical techniques described in Coplen (1973). Isotopic compositions of the 1991 samples were determined in WRD Menlo Park (California) laboratory supervised by Carol Kendall, by procedures described in Kendall and Coplen (1985). In addition, selected minor and trace elements of several samples (water, drilling mud, slurries), collected during the drilling, were determined by instrumental neutron-activation analysis (INAA) at the USGS laboratory in Denver, Colorado, using techniques adapted from those outlined in Zielinski and others (1977) and in Dodge and others (1982). These data are considered here only to the limited extent they might bear on interpretation of the composition of post-drilling water samples, but are given in full in Tilling and Jones (1991a, Tables 5-8).

Hoping possibly to gain insights in addition to those from interpretation of the chemical analyses alone, we (Tilling and Jones, 1990) evaluated normative salt assemblages computed from selected analyses of Hawaiian waters using the SNORM computer program (Bodine and Jones, 1986; Jones and Bodine, 1987); the types and proportions of simple salts so computed are listed in Tilling and Jones (1991a, Tables 1214). However, it turned out that both the raw analytical data and the SNORM salt assemblages demonstrated equally well the short-term and long-term temporal variations in the composition of the waters discussed below. In this paper, we consider only the raw 


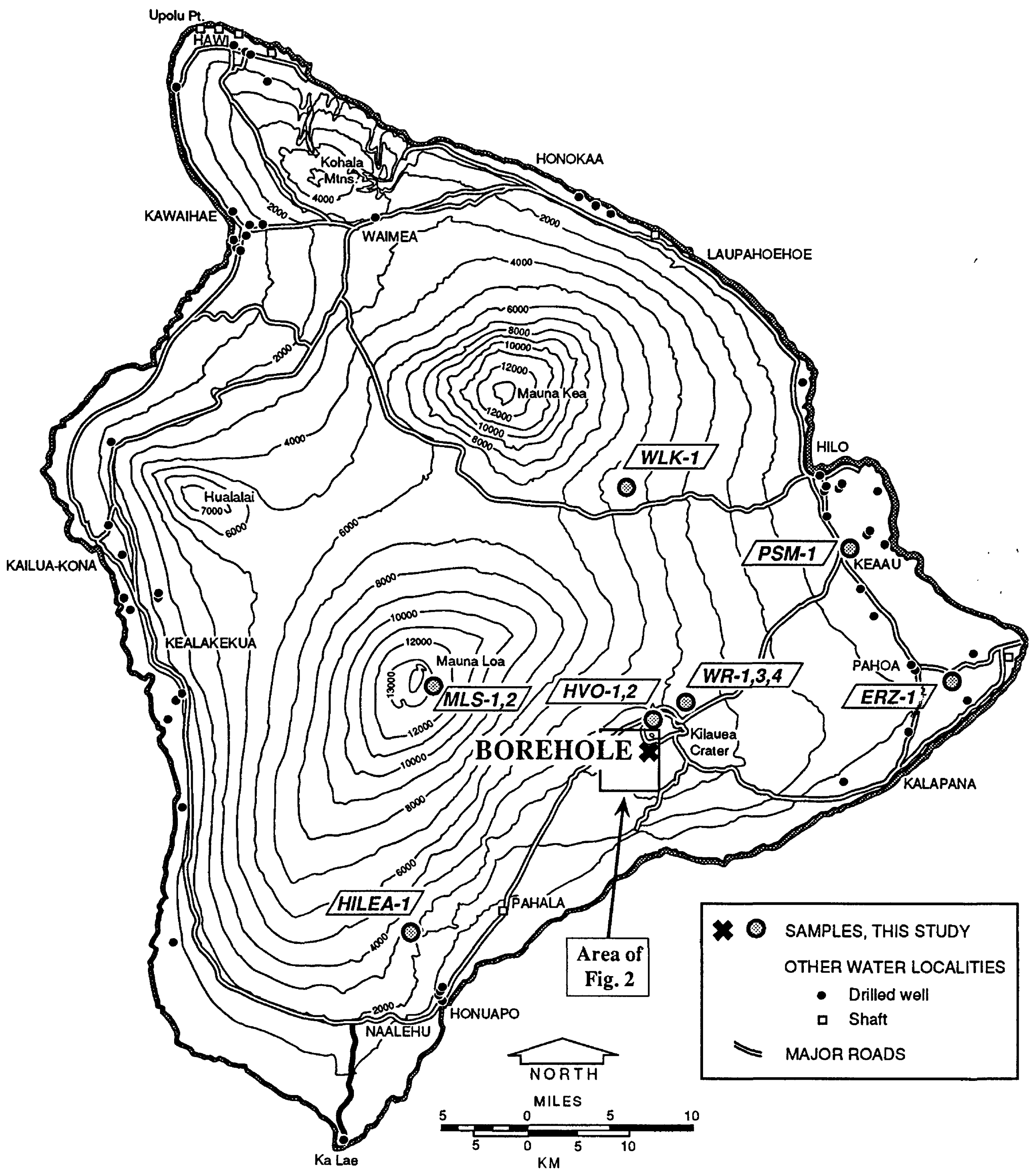

Fig. 5 Sample location map of the waters analyzed in this study; analytical data and other information for the samples are given in Tables 1, 2, and the Appendix. The base map modified from Anonymous (1970, Plate 15); to avoid clutter, the locations of springs, test holes, water shafts and tunnels are not shown in this figure. 
analytical data; unless otherwise indicated, all data discussed or plotted in this paper are from Tilling and Jones (1991a).

\section{COMPOSITION OF SUMMIT-BOREHOLE WATERS}

The waters from the 1262-m-deep research borehole are unique in that they constitute the only analyzed samples of thermal water directly above Kilauea's summit magma reservoir. There are no other drill holes in the summit region deep enough to penetrate the regional water table. Nearly all other Hawaiian waters previously analyzed are from wells and springs at lower elevations, in areas much closer to the coast (e.g., Swain 1973; McMurtry and others, 1977) and tap the salt water/freshwater interface (Ghyben-Herzberg lens), which in Kilauea's east-rift zone is perturbed locally by hightemperature geothermal systems (Fournier, 1987; Thomas, 1987; Kauahikaua, 1993).

\section{Possible modification by drilling mud and/or water?}

The presence of suspended drilling mud in all of the water samples collected in 1973-76, together with the fact that return circulation was never achieved during drilling, raises the question that the compositions of the borehole waters (Table 1) may perhaps have been modified by contact with drilling mud and/or by mixing with drilling water. This question cannot be addressed directly because there is not a pre-drilling datum for the composition of water beneath Kilauea summit. Nonetheless, we believe that the summit borehole samples we studied, with possible exception of the those collected through February 1974, were only affected minimally, if at all, by the drilling water or mud for the following reasons:

(1) The first sample (KBW-1, Table 1) was not collected until 4 September 1973, nearly two months after cessation of drilling and nearly a month after in-hole temperature logs (Fig. 3A,B) indicated that the drilling-caused thermal disturbance already had been recovered. We admit, however, that the chemical disturbances of the drilling may not have been fully dissipated by the time of the first sampling. This is suggested by the observation that the first three samples collected (in September-October 1973) are relatively lower in $\mathrm{Mg}, \mathrm{K}, \mathrm{SO}_{4}, \mathrm{~B}, \mathrm{SiO}_{2}$, and TDS and are isotopically heavier compared to the 1974 samples (Table 1). These relations may possibly be interpretated as recovery from solute dilution by drilling fluids, but the variations in $\mathrm{Na}$ concentration are inconsistent with such an interpretation. A critical question to be answered is: Is the flow through the borehole sufficient to sweep out all the chemical effects of the drilling in only two months? We do not have an answer, but a typical (perhaps minimum?) flow rate for water in basalts on the Island of Oahu is about 1 
meter/year (Warren Wood and Cliff Voss, oral communication, April 1993). Thus, if this rate is applicable to the summit borehole (nominal diameter $20 \mathrm{~cm}$ ) and even allowing for some plugging of fractures by drilling mud, the clearing of contaminant fluids could be accomplished in about 3 months, or by the end of 1973 or early 1974 . If so, the compositional variations observed for samples collected after February 1974 definitely should not reflect any drilling effects.

(2) The drill water (from same well as sample PSM-1, Table 2) is substantially more dilute than the borehole waters, by one or more orders of magnitude for the major cations and anions (compare analysis for PSM-1 with borehole analyses). Thus, unless the initial (uncontaminated) hydrothermal fluids were very highly saline, the effects of possible contamination by drill water appear to be negligibly small-too small to be detected within analytical error .

(3) A qualitative cobalt tracer experiment conducted during the drilling (Fig. 6) showed that, after an initial sharp increase following the addition of the tracer (cobaltus nitrate) in mid-June 1973, the concentration of Co-which can be determined precisely by INAA techniques-in both the drill water and the mud (Fig. 6) decreased exponentially with subsequent preparations of drilling mud using fresh drill water. By 8 July 1973, the concentration of Co had been diluted from a maximum of 66.1 and $4.5 \mathrm{ppm}$ to 27.4 and $0.111 \mathrm{ppm}$ for mud and drill water, respectively (Tilling and Jones, 1991a, Tables 5 and 6). The Co concentrations of borehole waters sampled in the period September 1973-February 1974 ranged between 0.004 and $0.037 \mathrm{ppm}$ with no apparent temporal trend, bracketing the value of $0.022 \mathrm{ppm}$ Co for uncontaminated drill water (Tilling and Jones, 1991a, Table 7). Because Co is readily absorbed by the drilling mud, the concentration of $\mathrm{Co}$ in water was necessarily short-lived. Nonetheless, the results of the cobalt tracer experiment, while hardly definitive, provide permissive evidence that possible modification of the composition of borehole water samples by the drilling mud or the drill water was negligible.

The relatively high concentration of $\mathrm{Ba}$ in the water samples $(3.3-11.0 \mathrm{ppm})$ through February 1974 does suggest possible contamination with the drilling mud (382 ppm Ba) (Tilling and Jones, 1991a, Table 7); Ba concentrations in thermal waters rarely exceed $0.5 \mathrm{ppm}$ (Cathy Janik, written communication, February 1993). It should be emphasized, however, according to the drilling company (Water Resources International, Inc., Honolulu, Hawaii), small amounts $(<1 \%)$ of lime were mixed on occasion with the bentonite mud, but no barite additive was used as an abrasive compound during the drilling (William Craddick, President, Water Resources International, Inc., oral communication, March 1993). Even so, if the Ba was taken 


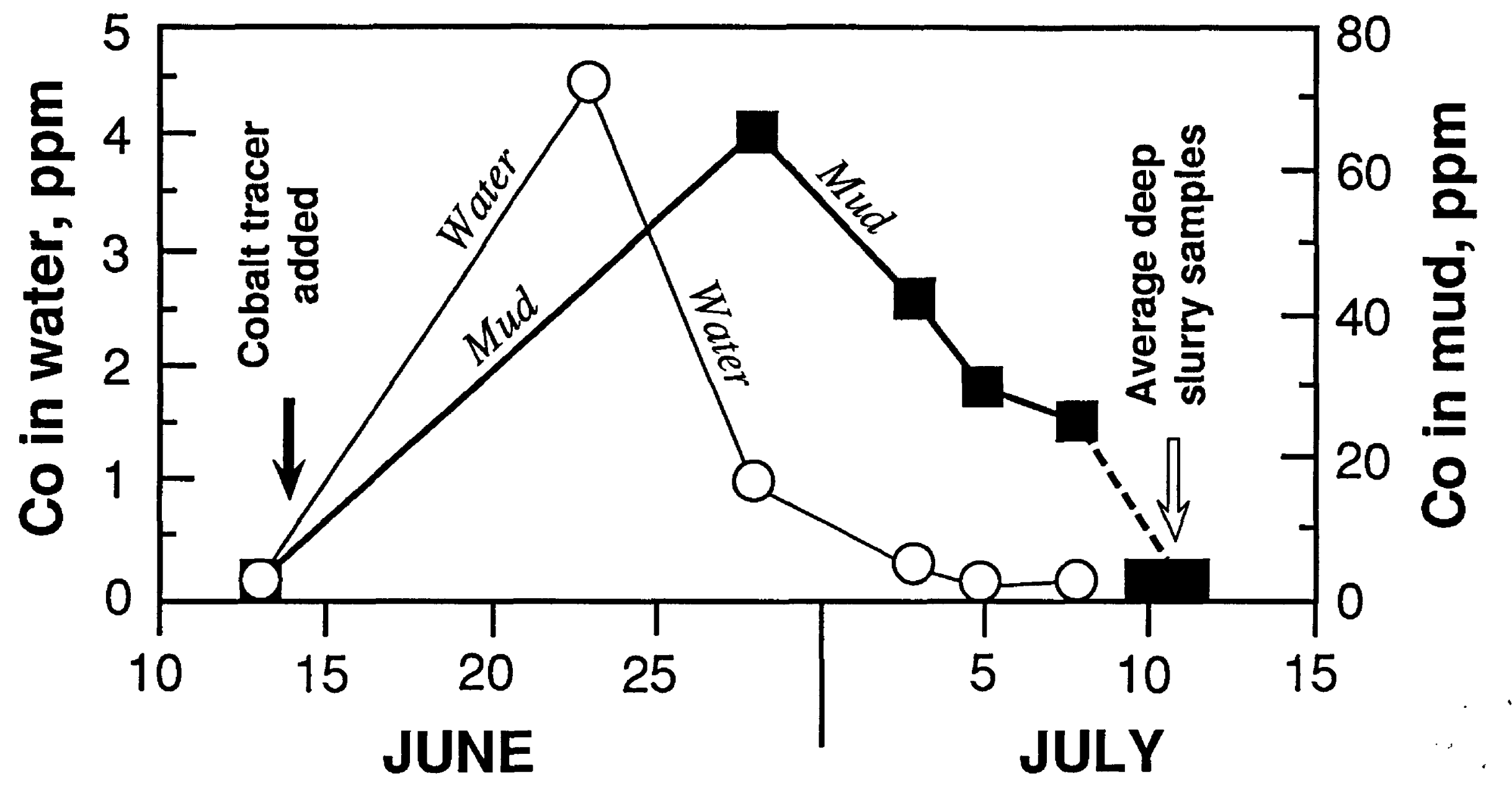

Fig. 6. The decay of Co concentration-in the water and the mud (bentonite)-with time after addition of the Co-nitrate tracer to the drilling mud. (Data source: Tilling and Jones, 1991a, Tables 5-8). The deep slurry samples (at $946 \mathrm{~m}, 1037 \mathrm{~m}$, and $1128 \mathrm{~m}$ depths) were collected on 10-11 July 1973, during formation testing of the borehole after cessation of drilling on 9 July (George V. Keller, 1973, written communication). The first borehole water sample collected for this study was on 4 September 1973, more than 2.5 months after the addition of tracer. 
up in exchange sites for $\mathrm{Na}$ with the concomitant dissolution of any barite interstitial in the bentonite, this would increase the amount of $\mathrm{Na}$ and $\mathrm{SO}_{4}$ in solution. However, calculations indicate that the highest $\mathrm{SO}_{4}$ concentrations that can result from such an exchange process would be less than $3 \%$ of the $\mathrm{SO}_{4}$ levels measured for the postdrilling 1973 samples, based on the highest measured Ba value of $37.9 \mathrm{ppm}$ in sample KELL-2, collected on 23 June 1973 (Tilling and Jones, 1991a, Table 6). Moreover, it must be remembered that the INAA technique is not sufficiently sensitive for reliable determinations of $\mathrm{Ba}$ at concentration levels under discussion (Phillip Baedecker, oral communication, April 1993).

(4) As will be seen, the oxygen and hydrogen isotopic ratios of the drill water are quite distinct from those of the summit-borehole waters.

\section{Comparison with other Hawaiian waters}

Figures 7 and 8 compare the composition of the summit-borehole waters with other waters from the Island of Hawaii. In terms of major-cation distribution, the thermal waters from the borehole do not differ appreciably from other Hawaiian waters. Except for the four samples collected in 1976 and 1991 (KBW-12, KBW-13, GT24SI91, and GT35SI91, Table 1), all other borehole waters plot toward the $\mathrm{Na}+\mathrm{K}$ corner in a ternary plot (Fig. 7) of $\mathrm{Mg}-\mathrm{Ca}-(\mathrm{Na}+\mathrm{K})$, as commonly observed for thermal waters worldwide (e.g., White and others, 1963; Giggenbach, 1988). Similarly, the borehole waters (agair except for the 1976 and 1991 samples) plot closer to the $\mathrm{K}$ apex in a ternary diagram $\mathrm{Mg}$ Ca-K (not shown), within the broad field defined by many thermal waters worldwide. The difference between the 1976-91 samples from the 1973-75 samples is discussed later in connection with the temporal variation in composition. Perhaps significantly, the borehole waters are similar in $\mathrm{Ca}-\mathrm{Mg}-(\mathrm{Na}+\mathrm{K})$ distribution to the interstitial waters of weathered Hawaiian basaltic tephra (Fig. 7) studied by Hay and Jones (1972).

In terms of major-anion distribution, however, the summit-borehole waters and the perched water samples from the Wright Road boreholes (WR-1, WR-3, WR-4, Table 2)-about $8 \mathrm{~km}$ northeast of the summit borehole (Fig. 5) share a distinctive geochemical signature: they too are very low in chloride relative to sulfate and carbonate concentrations compared to other Hawaiian waters (Fig. 8). The low-Cl signature of waters in the Kilauea summit region may reflect the fact that they are the most distant from the ocean and, hence, have the least opportunity to acquire seawater solutes through mixing or aerosol addition. Alternatively, the low- $\mathrm{Cl}$ signature could simply result from minimal contribution of volcanic $\mathrm{HCl}$ to the part of the Kilauea hydrothermal system in the summit region. However, a recent study indicates that marine aerosols can make a major 


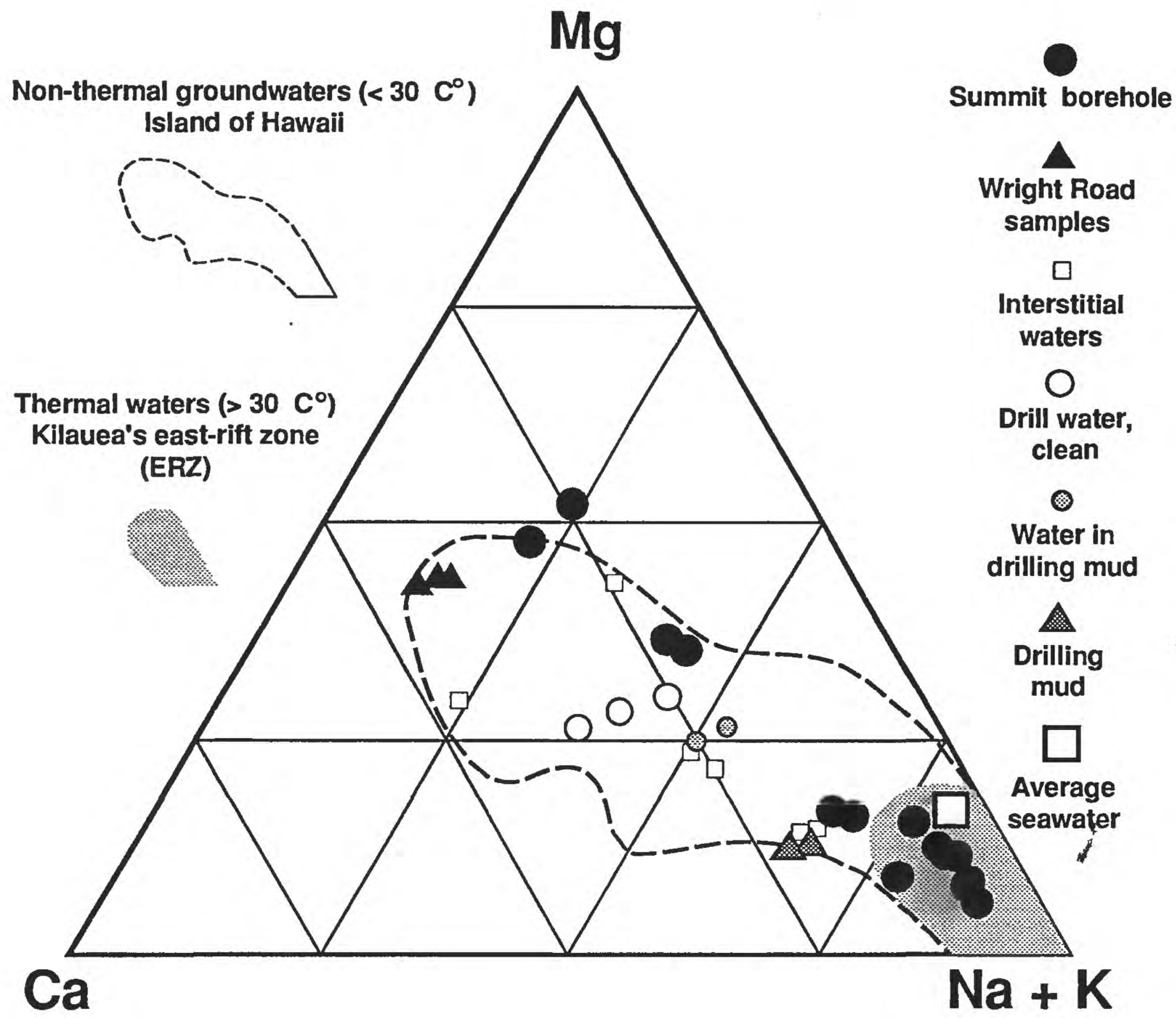

Fig. 7. $\mathrm{Mg}-\mathrm{Ca}-(\mathrm{Na}+\mathrm{K})$ ternary diagram comparing Kilauea summit-borehole waters, thermal waters from its east-rift zone, nonthermal groundwaters from the Island of Hawaii, and average seawater. The temporal variation of the su mmit-borehole waters-relative decrease of $(\mathrm{Na}+\mathrm{K})$ with time-is clearly evi dent in this plot (see text). Concentration data in this and Figures 8, 9A, and 10 are converted to meq/L before recomputing to $100 \%$. The Wright Road samples (Fig. 5), which are geographically closest to the summit-borehole samples, are from non-thermal perched water approximately $3 \mathrm{~km} \mathrm{NE}$ of Kilauea caldera (in Volcano Village). "Clean" drill water refers to samples from the PSM-1 well (Table 2) before mixing with mud (bentonite), while the "water in drilling mud" (collected on 5 and 8 July 1973) is taken from the drilling mud pond, i.e., after contact with mud. "Interstitial" waters are extracted from soils, paleosols, a nd clays derived from the weathering of tephra of the Keanakakoi and Pahala Formation (see Hay and Jones, 1972). [Other data sources: Tables 1 and 2, this paper; Swain, 1973; McMurtry and others, 1977; Kroopnick and others, 1978; Thomas, 1984; Hem, 1989; Tilling and Jones, 1991a]. 


\section{$\mathrm{SO}_{4}$}

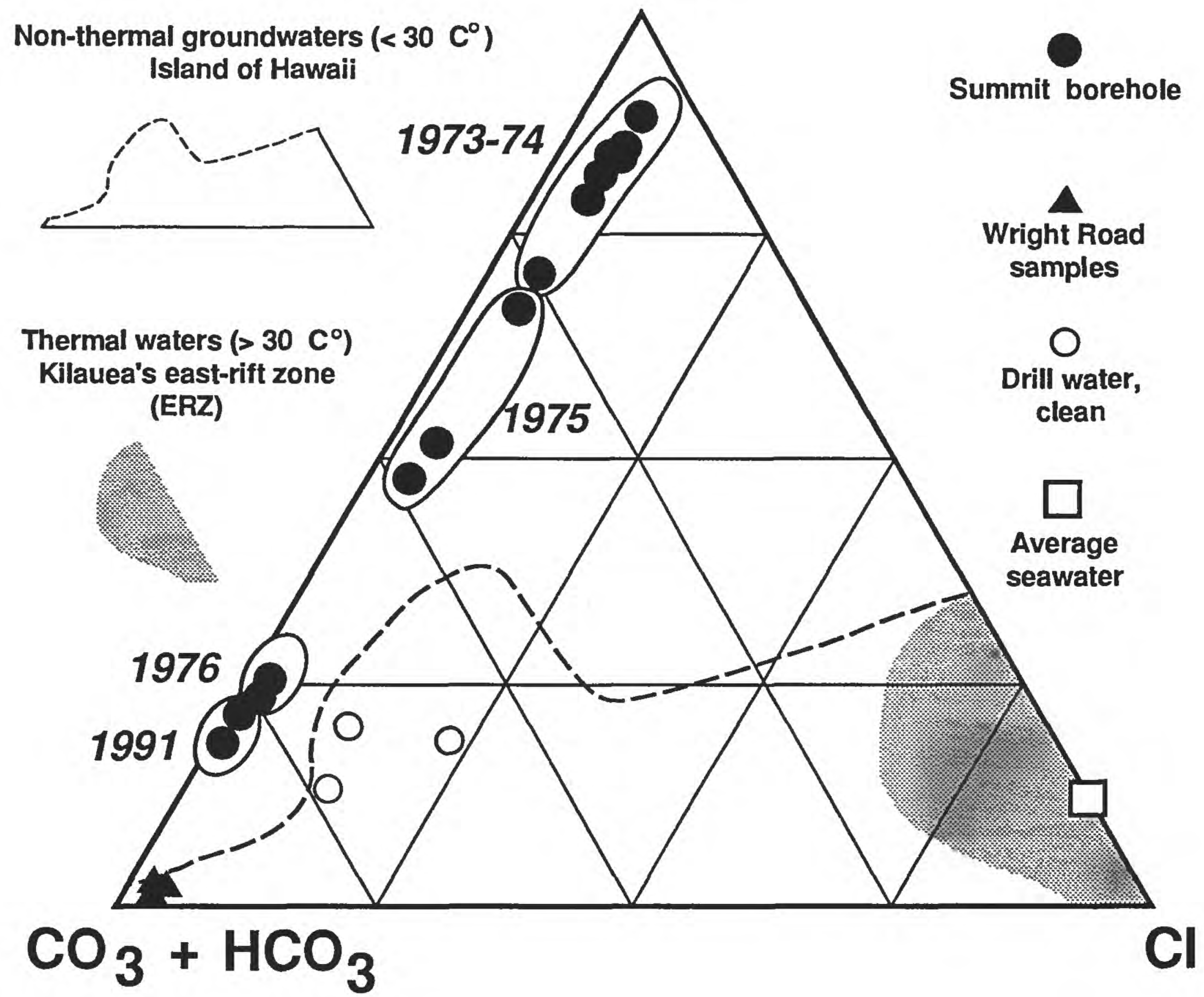

Fig. 8. $\mathrm{SO}_{4}-\left(\mathrm{CO}_{3}+\mathrm{HCO}_{3}\right)-\mathrm{Cl}$ ternary diagram comparing Kilauea summit-borehole waters, thermal waters from Kilauea's east-rift zone, nonthermal groundwaters from the Island of Hawaii, and average seawater. The temporal variation of the summit-borehole watersrelative decrease of $\mathrm{Cl}$ with time-is well illustrated in this plot (see text). The types and compositional fields of waters - volcanic," "mature geothermal," "peripheral," and "steamheated" - are taken from Giggenbach (1992, Fig. 1). Plot symbols and data sources [excluding Hay and Jones (1972)] same as for Figure 7. 
contribution to ground waters in the central part of the Murray Basin, Australia, hundreds of kilometers from the ocean (Jones and others, 1994). Thus, there is no reason to rule out the possibility that some of $\mathrm{Cl}$ in the Hawaiian waters, even those far inland, can also be recycled.

The carbonate-(or sulfate-) rich (relative to $\mathrm{Cl}$ ) waters, such as observed for the summit-borehole samples, can develop from silicate-hydrolysis reactions during weathering of volcanic source rocks (e.g., Jones, 1966; Jones and others, 1969), or from absorption of volcanic gases such as $\mathrm{CO}_{2}, \mathrm{SO}_{2}$ and $\mathrm{H}_{2} \mathrm{~S}$ (e.g., Giggenbach, 1992a), or from these processes combined. The 1973-75 borehole samples plot within the compositional field for "steam-heated waters" (Fig. 8), but the waters are near neutural rather than acidic, as would be expected from the Giggenbach (1992a) model. However, the near-neutral $\mathrm{pH}$ values would be expected if the solutes represent dissolution of sublimates from fracture surfaces, as we suggest further in the discussion (p. ?).

\section{Comparison with waters in other volcanic regions}

We also compared the summit-borehole samples with waters in other volcanic regions, including hydrothermal systems associated with active volcanoes (Figs. 9 and 10). A comparison of major-cation distribution (Fig. 9A) is not especially diagnostic, other than showing that the compositional field for the Hawaiian waters-borehole and all other-largely coincides with that defined by many other volcanic regions. It is interesting to note in Figure 9A, however, that the average compositions for non-thermal waters from several major basaltic fields-Reykjanes Peninsula of southwestern Iceland (RKJ), neovolcanic zone of northeastern Iceland (NEI), Columbia River Basalt (CRB), and Snake River Basalt (SRB)-plot within the fields for thermal waters worldwide and for Hawaiian waters. In assessing geothermal fluids, however, a plot of $\mathrm{Na}-\mathrm{K}-\mathrm{Mg} 0.5$ may yield more information than a plot of $\mathrm{Ca}-\mathrm{Mg}-(\mathrm{Na}+\mathrm{K})$ (see, e.g., Giggenbach, 1988; Fournier, 1990). In such a plot (Fig. 9B), non-thermal waters from Hawaii plot within a very restricted area toward the $\mathrm{Mg}$ corner; within this small area also would plot (but not shown) the average compositions (RKJ, NEI, CRB, and SRB) of non-thermal waters produced from weathering of basalt. In contrast, thermal waters tend to plot away from the $\mathrm{Mg}$ corner and have a much greater range of variation, as demonstrated by the Hawaiian and Icelandic thermal waters plotted. The summit-borehole waters, as distinguished from most thermal waters of Kilauea's east-rift zone, plot close to, or, for the 1976 and 1991 samples, within the field for non-thermal waters (Fig.9B).

A HCO $3-\mathrm{SO}_{4}-\mathrm{Cl}$ ternary plot shows that the Kilauea summit-borehole waters are distinctly lower in $\mathrm{Cl}$ (proportionate to $\mathrm{HCO}_{3}$ and $\mathrm{SO}_{4}$ ) than all Hawaiian waters, non- 


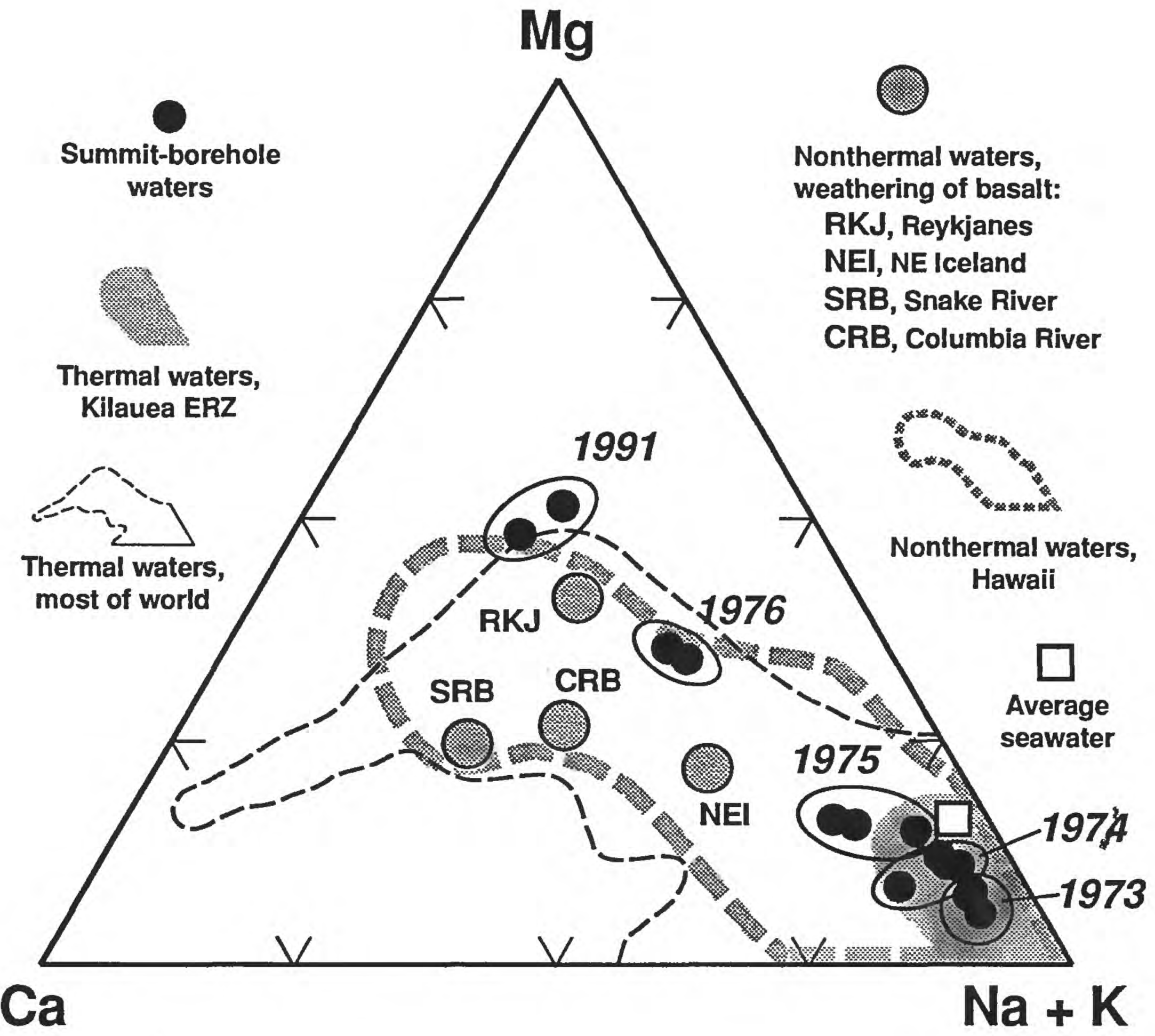

Fig. 9 A. $\mathrm{Mg}-\mathrm{Ca}-(\mathrm{Na}+\mathrm{K})$ ternary diagram comparing Kilauea thermal waters (summit and eastrift zone) with thermal waters from other volcanic regions, including selected hydrothermal systems at active volcanoes. Data summarized here for thermal waters worldwide are not intended to be all-inclusive, but rather to demonstrate that the compositional field is relatively large; however, the overwhelming majority of points plot near the $\mathrm{Na}+\mathrm{K}$ corner. Also shown are average compositions of non-thermal waters associated with normal weathering in selected basaltic provinces: CRB, Columbia River Basalt (U.S.A.); SRB, Snake River Basalt (U.S.A.), and RKJ, Reykjanes Peninsula (SW Iceland); and NEI (neovolcanic zone, NE Iceland). [Data sources: Tables 1 and 2, this paper; White and others, 1963; Arnórsson, 1970, 1979; Arnórsson and Sigurdsson, 1974; Gislason and Eugster, 1987; Giggenbach, 1988; Wood and Fernandez, 1988; Giggenbach and others, 1990; Sturchio and others, 1988; Marini and others, 1991; Martini and others, 1990; Delfin and others, 1992]. 


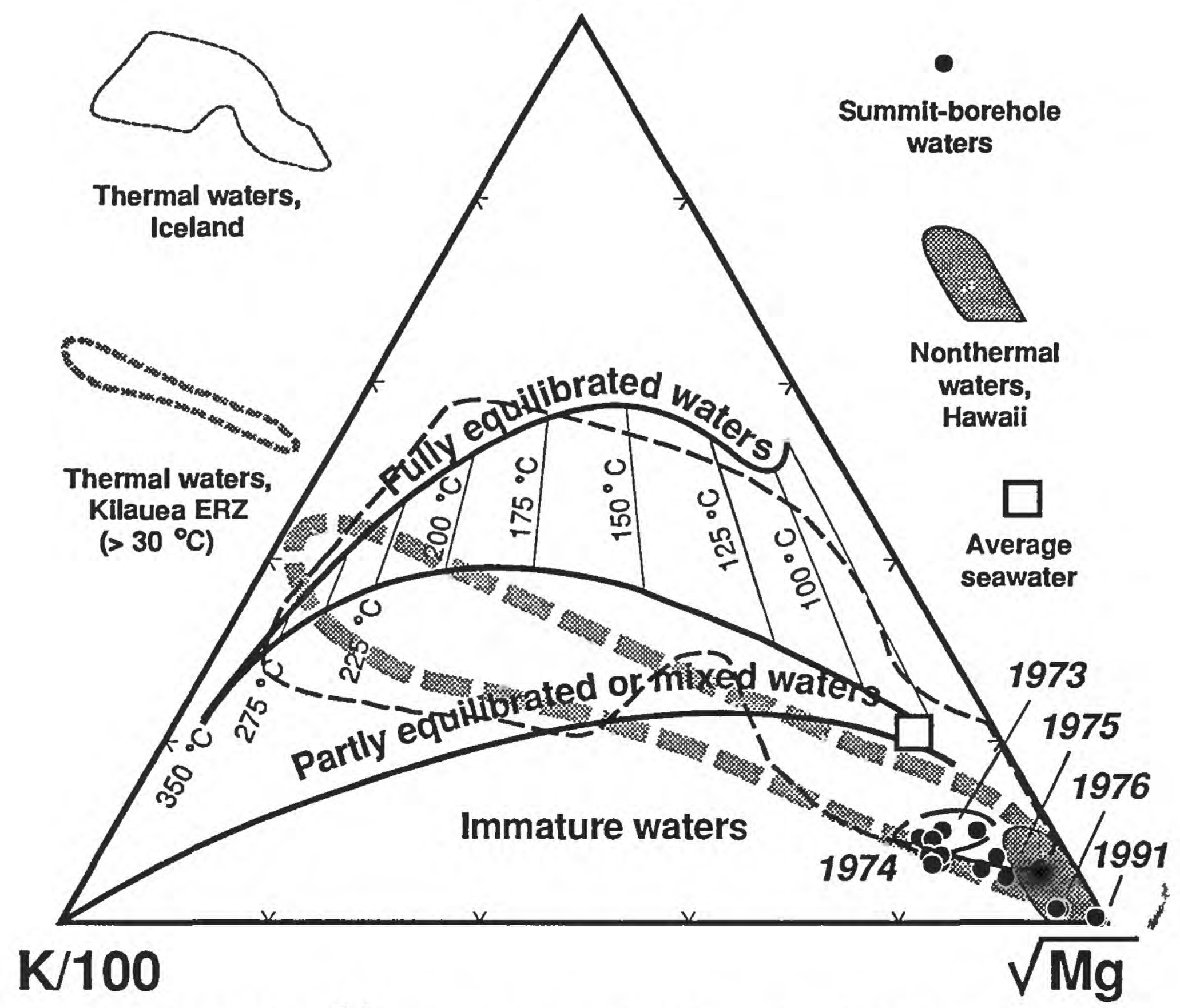

Fig. 9 B. $\mathrm{Na} / 1000-\mathrm{K} / 100-\mathrm{Mg}^{0.5}$ ternary plot (modified from Fournier 1990, Fig. 4) comparing much of the same data sets as plotted in Figure 9A. The significance of this type of diagram in estimating the temperature of the last water-rock equilibration from geochemical thermometers is discussed in detail by Giggenbach (1988) and by Fournier (1990). Briefly stated, samples that plot close to the "fully equilibrated" curve generally yield reliable estimates of geothermometer temperatures, and those that fall within the "immature waters" field (toward the Mg corner) are unsuitable for temperature estimation; the summit-borehole waters are clearly "immature" and unsuitable for temperature estimation. Samples that plot within the "partly equilibrated or mixed" field allow less reliable temperature estimates and evaluation of models of mixing of waters equilibrated at difference temperatures. In contrast to Figure 9A, nonthermal waters are generally distinguishable from thermal waters and define a very small compositional field near the $\mathrm{Mg}$ corner, within which plot all nonthermal waters from Hawaii ( 94 samples) as well as several thermal waters from the summit borehole and Kilauea's ERZ. The average compositions of waters from weathering of basalts (CRB, SRB, RKJ, and NEI) also are included within this field. Fields for thermal waters (e.g., for the ERZ of Kilauea and for Iceland), however, may stretch across large areas away from the $\mathrm{Mg}$ corner. [Data sources: Tables 1 and 2, this paper; Tilling and Jones, 1991a, Tables 7 and 8; Swain, 1973; Thomas, 1984; Kroopnick and others, 1978; Arnórsson and Sigurdsson, 1974; Arnórsson and others, 1983; Gislason and Eugster, 1987; Wood and Fernandez, 1988; Hem, 1989]. 
thermal and thermal.waters (Figure 10). Moreover, they also differ in similar fashion from the large majority of all thermal waters in other volcanic regions as well. Only a few thermal waters at Nevado del Ruiz, Colombia (Sturchio and others, 1988), B. Georginas, Guatemala (Giggenbach, 1988, Table 1), some localitiies in Iceland (Arnorsson and others, 1983), and Mount Pinatubo, Philippines (Delfin and others, 1992) also have this proportionately low-Cl signature (Fig. 10). Note in this figure, however, the average composition for Reykjanes Peninsula waters (RKJ) apparently reflects the influence of seawater solutes, while the waters of northeastern Iceland (NEI) and of the Columbia River Basalt (CRB) and Snake River Basalt (SRB) do not. In anion distribution, the Kilauea summit thermal waters are similar to groundwaters associated with normal weathering of basalt in a continental-interior setting (e.g., CRB, SRB) or with nonthermal waters in basalt in an ocean-island setting unaffected by seawater solutes through mixing or aerosol addition with seawater (e.g., NEI). Simply stated, the summit-borehole waters have geochemical attributes more similar to non-thermal waters in basaltic terranes produced by rock weathering, rather than to most thermal waters worldwide.

\section{Oxygen and hydrogen isotopes}

The oxygen and hydrogen isotope data for the summit-borehole and other Hawaiian water samples we studied are summarized in Figures 11 and 12. Basically, these isotope data extend the conclusion reached by McMurtry and others (1977) that most Hawaiiany waters are dominantly meteoric in origin. The "local meteoric water line" for the Island of Hawaii $\left(\delta \mathrm{D}=8.15 \delta^{18} \mathrm{O}+11.18\right)$, determined by rainfall and permafrost samples (Fig. $11)$, matches well the world meteoric water line $\left(\delta D=8 \delta^{18} \mathrm{O}+10\right)$ of Craig (1961). With exception of steam from geothermal test hole \# 2 within Kilauea's east-rift zone (ERZ), all other samples cluster about the "local" meteoric water line (Fig. 12). Except for a single sample, all other non-thermal Hawaiian groundwaters $\left(<30^{\circ} \mathrm{C}\right.$.) plot on or to the left of the "local" meteoric water line (i.e., isotopically lighter in $\delta^{18} \mathrm{O}$ or heavier in $\delta \mathrm{D}$ ). Although thermal waters $\left(\geq 30^{\circ} \mathrm{C}\right.$.) mainly plot to the right of the meteoric water line, the highest $\delta \mathrm{D}$ values (KBW-9 and KBW-10 at Kilauea summit, or the $54^{\circ} \mathrm{C}$ Malama-ki well in the ERZ) are not associated with the highest temperature thermal water $\left(93{ }^{\circ} \mathrm{C}\right.$ geothermal test hole \#2 in the ERZ). In comparison with thermal waters from other geothermal regions (see, for example, Giggenbach, 1992b), the thermal waters of Kilauea Volcano isotopically analyzed to date exhibit a much lower degree of oxygen isotope shift caused by rock-water interaction, perhaps reflecting relaitvely low temperatures and a high through-put of meteoric water, i.e., higher water/rock ratios. 


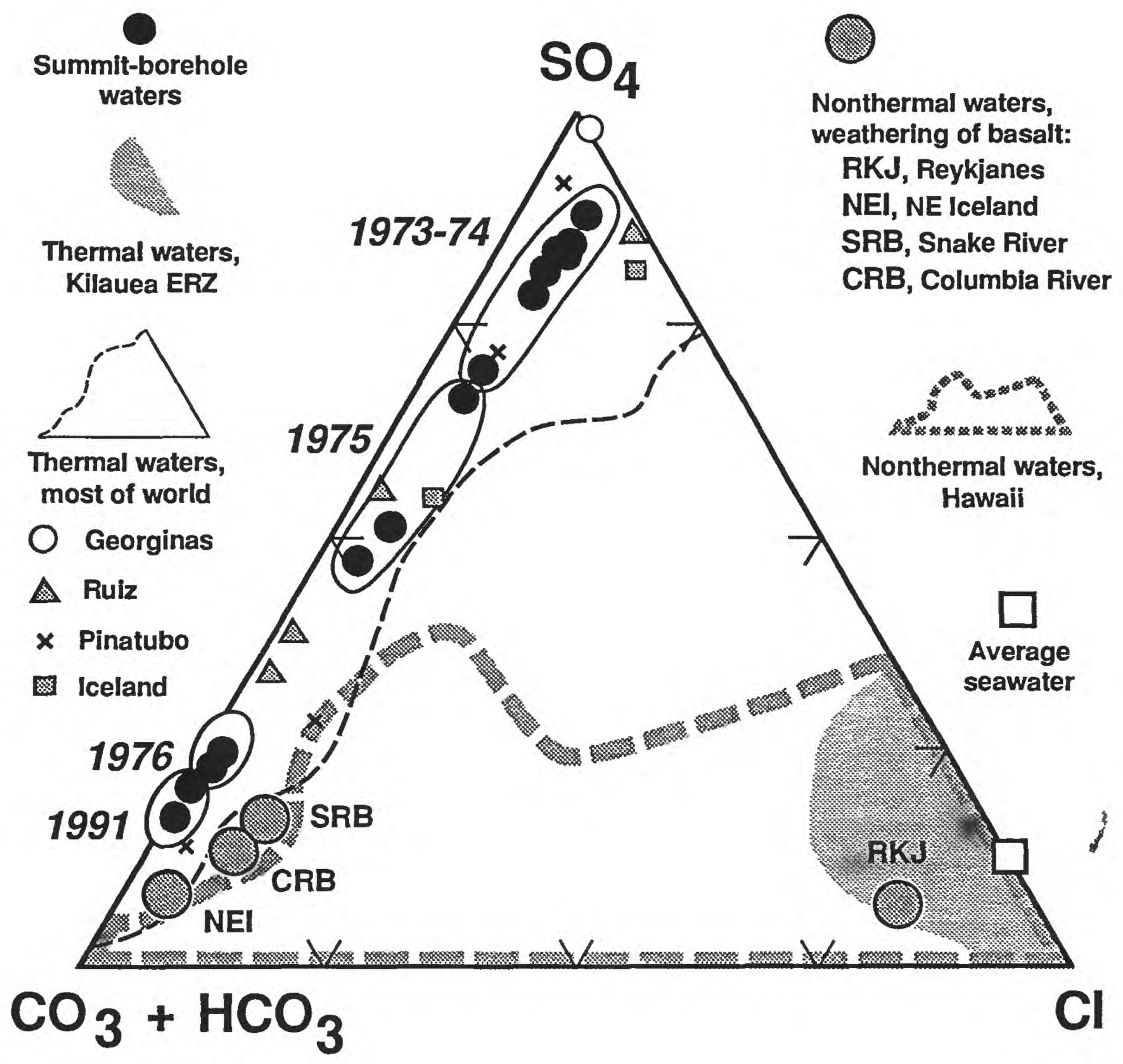

Fig. 10. $\mathrm{SO}_{4}-\left(\mathrm{CO}_{3}+\mathrm{HCO}_{3}\right)-\mathrm{Cl}$ ternary diagram comparing Kilauea thermal waters [summit and east-rift zone (ERZ)], thermal waters from other volcanic regions, including selected hydrothermal systems at active volcanoes, and average compositions of non-thermal waters associated with normal weathering in selected basaltic provinces. Temporal variation of the summit-borehole waters-relative increase of carbonates with time-is also clearly evident in this plot, but compositional distinction cannot be made between 1973 and 1974 samples. Plot symbols, unless otherwise indicated, and data sources same as for Figure 9. 


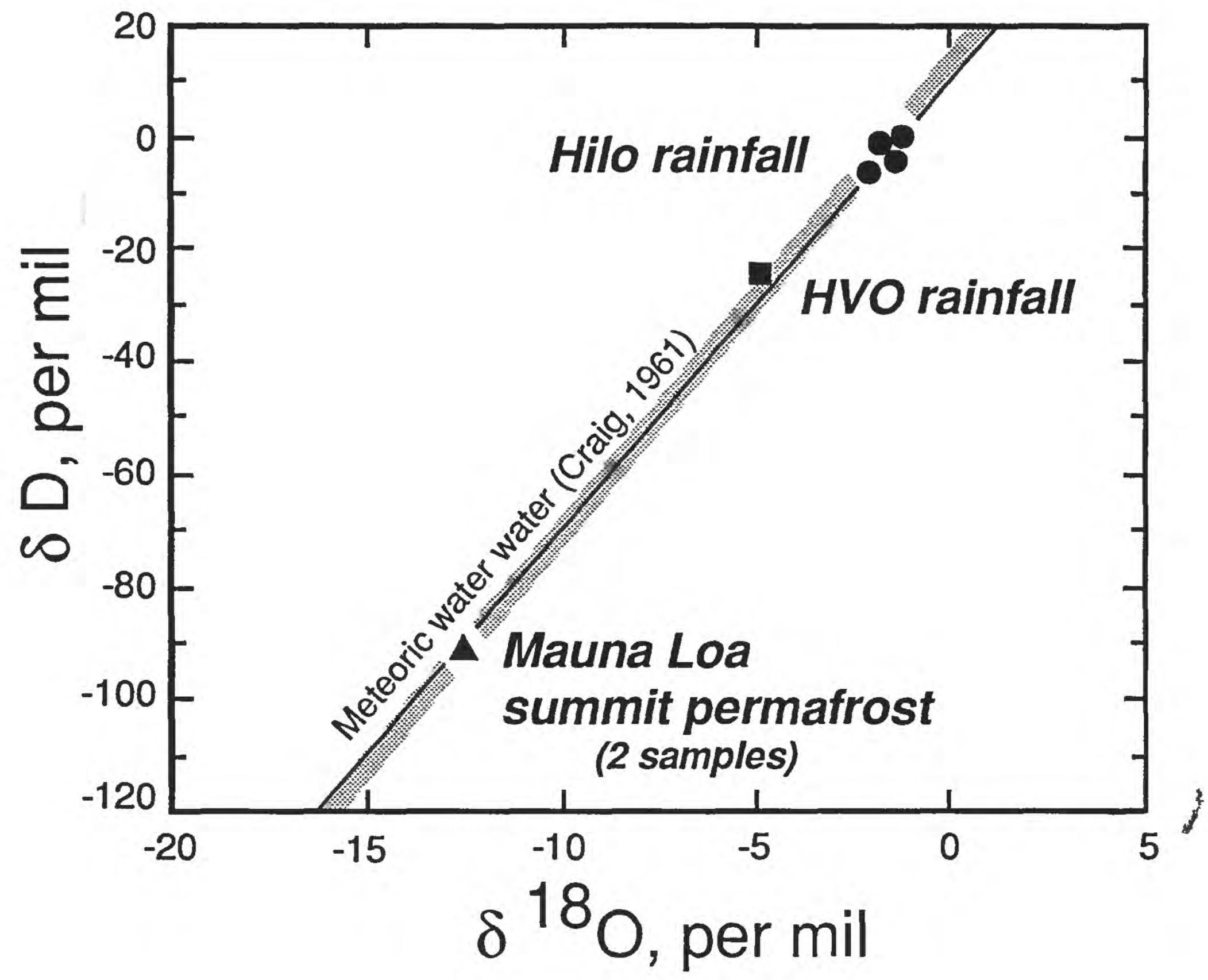

Fig. 11. Oxygen and hydrogen isotope compositions of Hawaiian rainfall and Mauna Loa permafrost samples, referenced to the "local" meteoric water line $\left(\mathrm{dD}=8.15 \mathrm{~d}^{18} \mathrm{O}+11.18\right)$, indicated by the broad shaded line, and to Craig's (1961) world meteoric water line ( $\mathrm{dD}=$ $8 \mathrm{~d}^{18} \mathrm{O}+10$ ), shown by the solid thin line. The estimated average analytical uncertainty for the data plotted here and in Figure 12 is \pm 1 for $d D$ and \pm 0.1 for $\mathrm{d}^{18} \mathrm{O}$. [Date sources: Table 2, this paper; McMurtry and others, 1977]. 


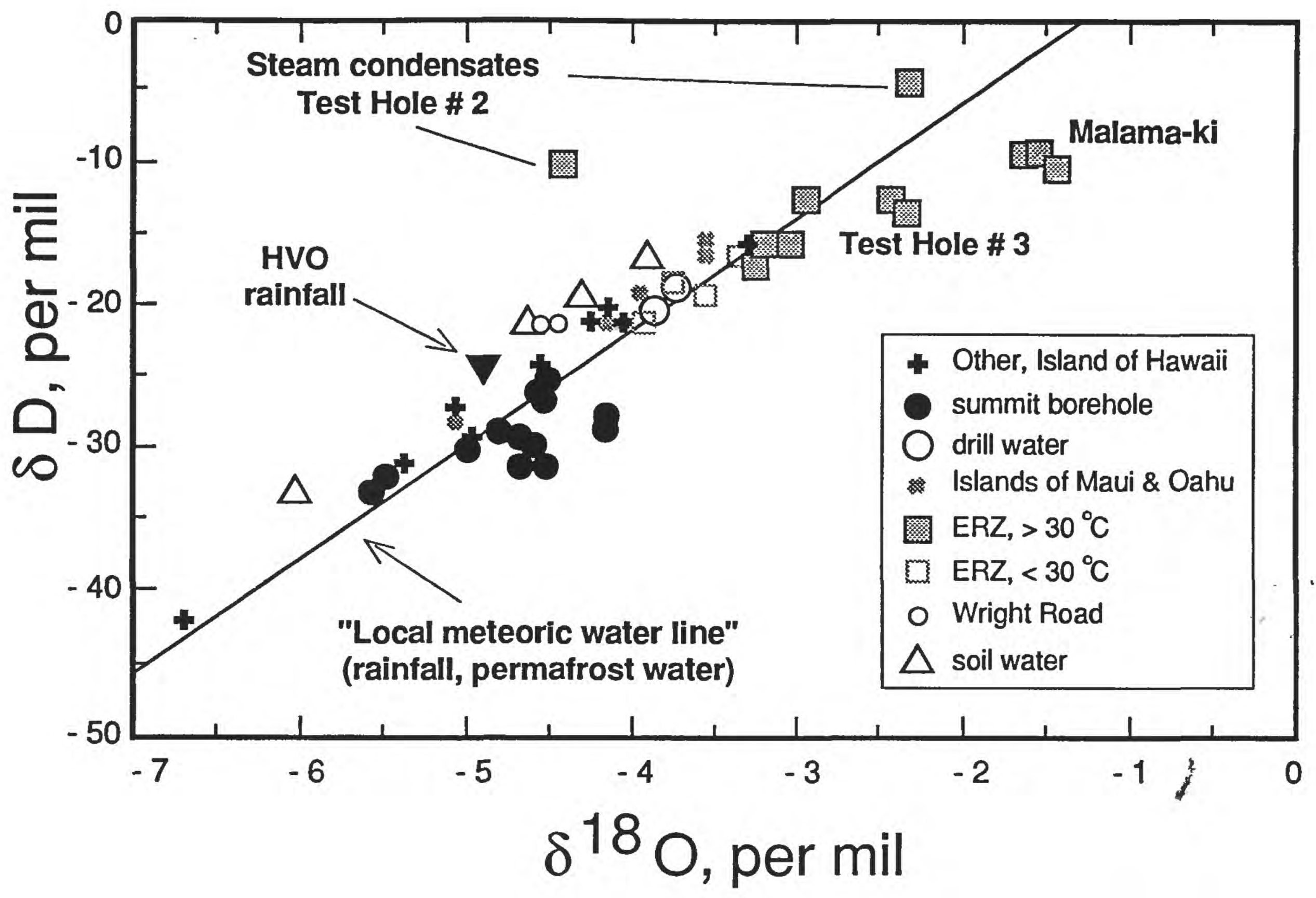

Fig. 12. Summary of oxygen and hydrogen isotope data for water samples analyzed in this study, compared with available isotopic data for other Hawaiian groundwaters and soil waters (see text). The reference is the "local" meteoritic line determined by the samples plotted in Figure 11. ERZ denotes waters from Kilauea's east-rift zone. [Data sources: Tables 1 and 2, this paper; McMurtry and others, 1977; unpublished USGS data of Craig Rightmire for soil waters analyzed in 1975.] 
The hydrogen isotope data show that the summit-borehole waters (Fig. 12) are most similar to the rainfall collected at HVO, suggesting that Kilauea's hydrothermal system must in part be recharged by infiltration of local rainfall. However, all of the summit-borehole waters have $\delta D$ values lower than that for the rainfall at HVO (Fig. 12), implying a probable contribution from somewhat higher elevations on the flanks of Mauna Loa (Scholl and others, 1993). In particular, the two 1991 samples (Table 1) and work in progress yield a calculated recharge elevations between 1,400 and 1,940 m A.S.L. (Scholl and others, 1992, 1993; USGS, unpublished data). We caution, however, that these prelimianry results may not necessarily apply for Kilauea's hydrothermal system as a whole because: 1) the available data are restricted to only a few samples from the very top of the hydrothermal system; 2) we do not know how these shallow samples are related to deeper, but as yet unsampled hydrothermal fluid within the borehole; and 3) the relationship between the hyrothermal system in the summit region and the system(s) in the east-rift zone is unknown. The available data suggest that the summit-borehole waters are isotopically distinct from the drill water or Mauna Loa summit waterThe waters of the ERZ have hydrogen isotopic ratios that are intermediate between Kilauea summit and Hilo rainfall (Fig. 11), reflecting elevation effects expectable from differences elevation between the summit $(\sim 1,245 \mathrm{~m}$ A.S.L) and Hilo (near sea level).

\section{TEMPORAL VARIATIONS IN COMPOSITION}

In addition to possessing an apparently unique, but not yet understood, low-Cl geochemical signature, the summit-borehole waters sampled during the 1973-76 period also exhibit important temporal variations in composition. These variations include relatively short-term changes (days to weeks) imposed on longer term trends (months to years) and record the complex interaction between rainfall and recharge, volcanic activity and degassing, the availability of leachable materials in fractures and pores along the water-flow path, and rock weathering (Tilling and Jones, 1990;1991b).

\section{Short-term variation: Rainfall dilution}

A sample (KBW-4) collected on 4 December 1973-two days after $37 \mathrm{~cm}$ of rain (as measured at HVO) had fallen in a three-day period-showed significant dilution of nearly all solutes (Table 1), clearly demonstrated by the principal cations (Fig. 13) and by $\mathrm{SO}_{4}$ and $\mathrm{Cl}$ (Fig. 14). Correspondingly, the concentration of $\mathrm{HCO}_{3}$ increased slightly (Fig. 14), reflecting the increased flushing and passage of recharge through the higher concentrations of $\mathrm{CO}_{2}$ in the soil zone accompanying and following the deluge. The dilution effects, which are also evident for boron, silica, and total dissolved solids (TDS) 


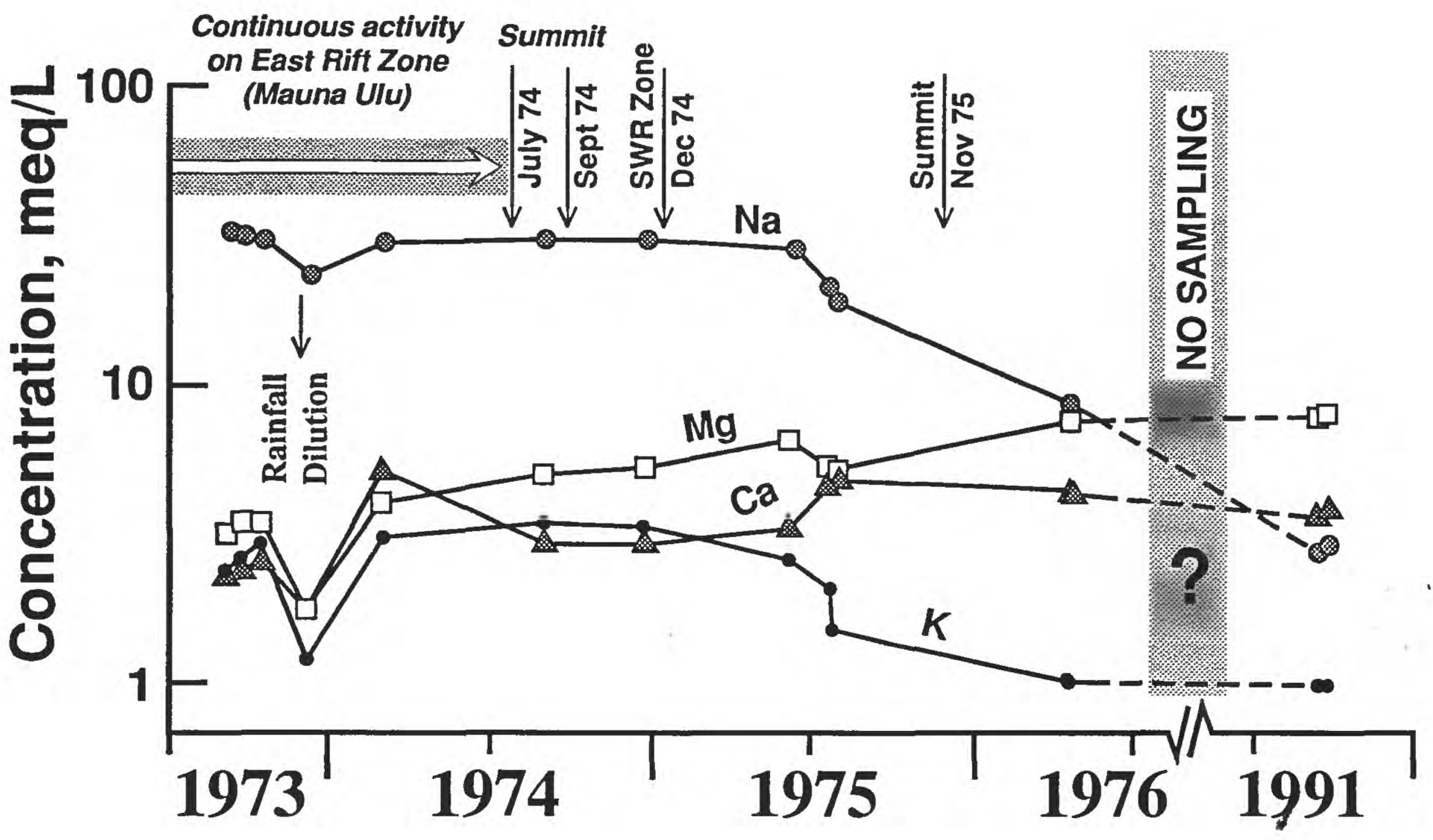

Fig. 13. Temporal variation of principal cations for the Kilauea summit-borehole waters, for the period September 1973-April 1976 and, following a 15-year hiatus in sampling, for AugustSeptember 1991 (data source: Table 1). Decrease in solute concentrations in early December 1973 is attributed to rainfall dilution (see text); rainfall-dilution effects are also clearly seen for some other chemical components not plotted ( $\mathrm{SiO}_{2}, \mathrm{~B}$, and total dissolved solids). Through midJuly 1974, Kilauea was continuously active on its upper east-rift zone at Mauna Ulu (see Fig. 1). Since then, Kilauea experienced a number of short-lived eruptions in the summit and southwestrift zone (SWR) region through 1975, as denoted by the arrows (see text for discussion). Except for two minor eruptions in the summit region in 1982, the eruptive activity at Kilauea during the 1976-1991 period was restricted to the east-rift zone (Peterson and Moore, 1987; Heliker and Wright, 1991; Mattox, 1993). 


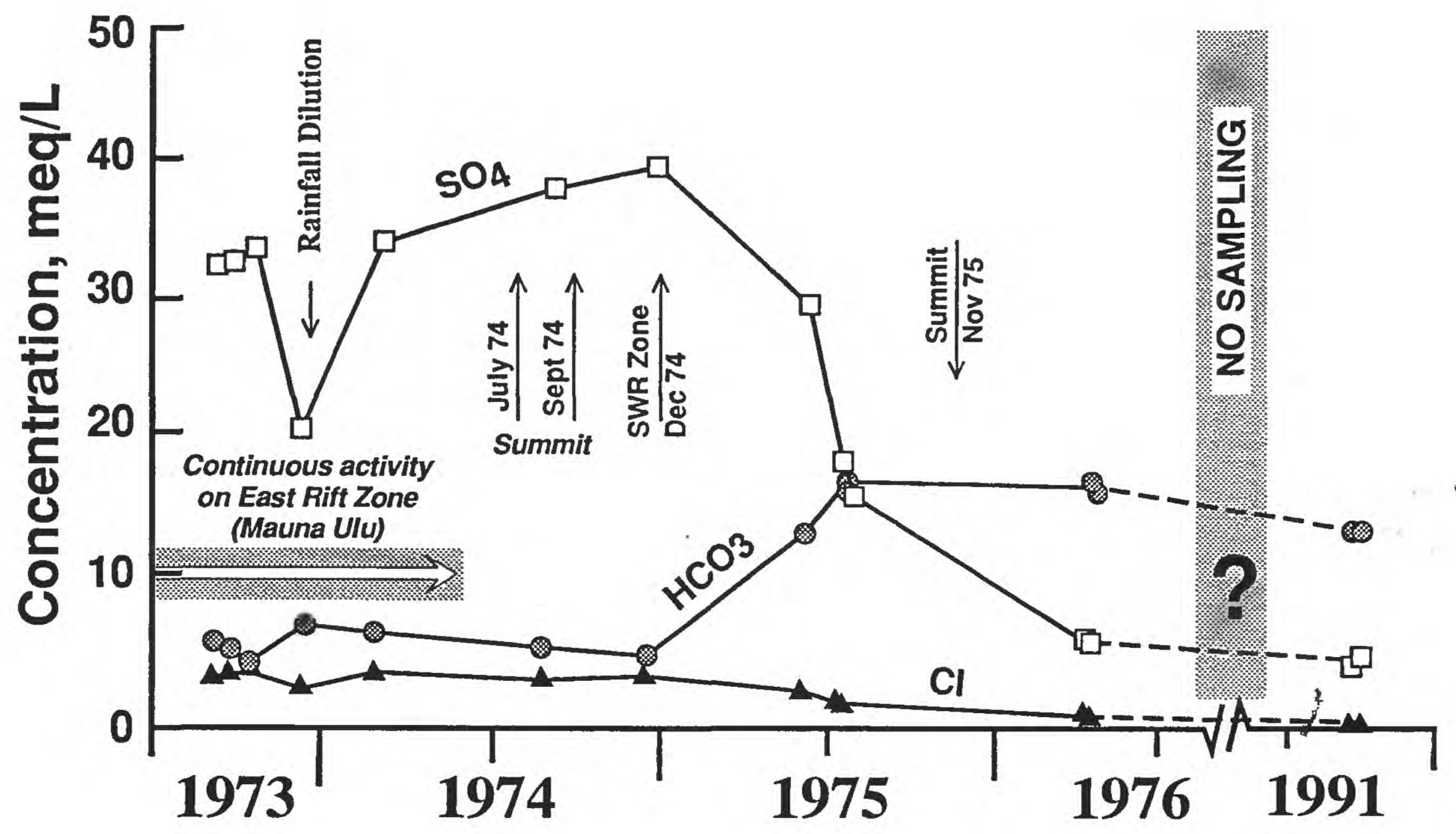

Fig. 14. Temporal variation of principal anions for the Kilauea summit-borehole waters during the same span of time as shown in Figure 13 (data source: Table 1). The dashed segments for the $\mathrm{SO}_{4}$ and $\mathrm{HCO}_{3}$ curves during early 1975 may better portray the actual trends, if indeed the 31 December 1974 eruption was instrumental in causing the compositional changes observed (see text). 
(Table 1), probably were produced by a combination of rainwater pouring down the borehole and increased regional lateral flow through the host basalts. Solute concentrations recovered or exceeded pre-heavy-rainfall levels by the time of the next sampling (21 February 1974), i.e., within about 2.5 months but conceivably much less. Because of the lack of more frequent sampling, the dilution-caused anomalies in solute concentrations could be much sharper than shown in Figures 12 and 13. Short-term variations in chemical composition of groundwaters brought about by intense precipitation have been observed elsewhere (e.g., White, 1968; Fritz and others, 1976; Giggenbach and Glover, 1975; Rowe and others, 1992a,b), but, to our knowledge, the rainfalldilution effects recorded by the summit-borehole waters represent the best documented example to date for Hawaiian waters.

\section{Longer term variations}

Other than the short-term rainfall dilution in late 1973, which reduced solute concentration by about a third, the summit-borehole waters collected in 1973-74 varied relatively little with possibly a slight, gradual increase in total solutes, largely reflecting increases in $\mathrm{Ca}, \mathrm{Mg}, \mathrm{K}, \mathrm{SO}_{4}, \mathrm{Cl}$, and $\mathrm{B}$ (Table 1, Figs. 13 and 14). The reason for the abrupt spike (sample KBW-5, Table1 and Fig. 13) in the overall gradual increase in $\mathrm{Ca}$ is not known. The compositions of the borehole waters were not measurably perturbed by the continuous east-rift eruption at Mauna Ulu through mid-July 1974, nor by the brief summit eruptions on 21-24 July 1974, 19 September 1974, and 29 November 1975 (Figures 12-14). In general, samples collected in the September 1973-June 1975 period are Na-sulfate-dominant, but samples collected after July 1975 are $(\mathrm{Mg}+\mathrm{Ca})$-bicarbonatedominant (Table 1). In detail, the transitions in dominant ions (in meq/L) with time is as follows:

$\mathrm{Na}-\mathrm{SO}_{4}\left(6 / 05\right.$ and 7/18/75) $\nrightarrow \mathrm{Na}-\mathrm{HCO}_{3}(7 / 24 / 75) \quad \Leftrightarrow \mathrm{Na}, \mathrm{Mg}-\mathrm{HCO}_{3}(4 / 17$ and 4/19/76) $\nrightarrow \mathrm{Mg}, \mathrm{Ca}-\mathrm{HCO}_{3}$ (8/09 and 9/13/91).

Shift caused by volcanic activity on 31 December 1974 . The compositional shift from sulfate-dominant to bicarbonate-dominant waters in 1975 is clearly evident in the temporal variations in anion concentrations (Fig. 14) and demonstrated by the dramatic increase in the ratio $\left(\mathrm{CO}_{3}+\mathrm{HCO}_{3}\right) / \mathrm{SO}_{4}$ (Fig. 15). This shift was not presaged by any obvious long-term compositional variation during the 1973-74 period. Unfortunately, because of the 6-months time lapse in sampling, whether the compositional shift was abrupt or gradual cannot be determined. However, we believe that the change in composition was probably abrupt, most likely related to volcanic degassing and attendant increase in partial pressure of $\mathrm{CO}_{2}$ associated with the eruptive and intrusive activity on 31 


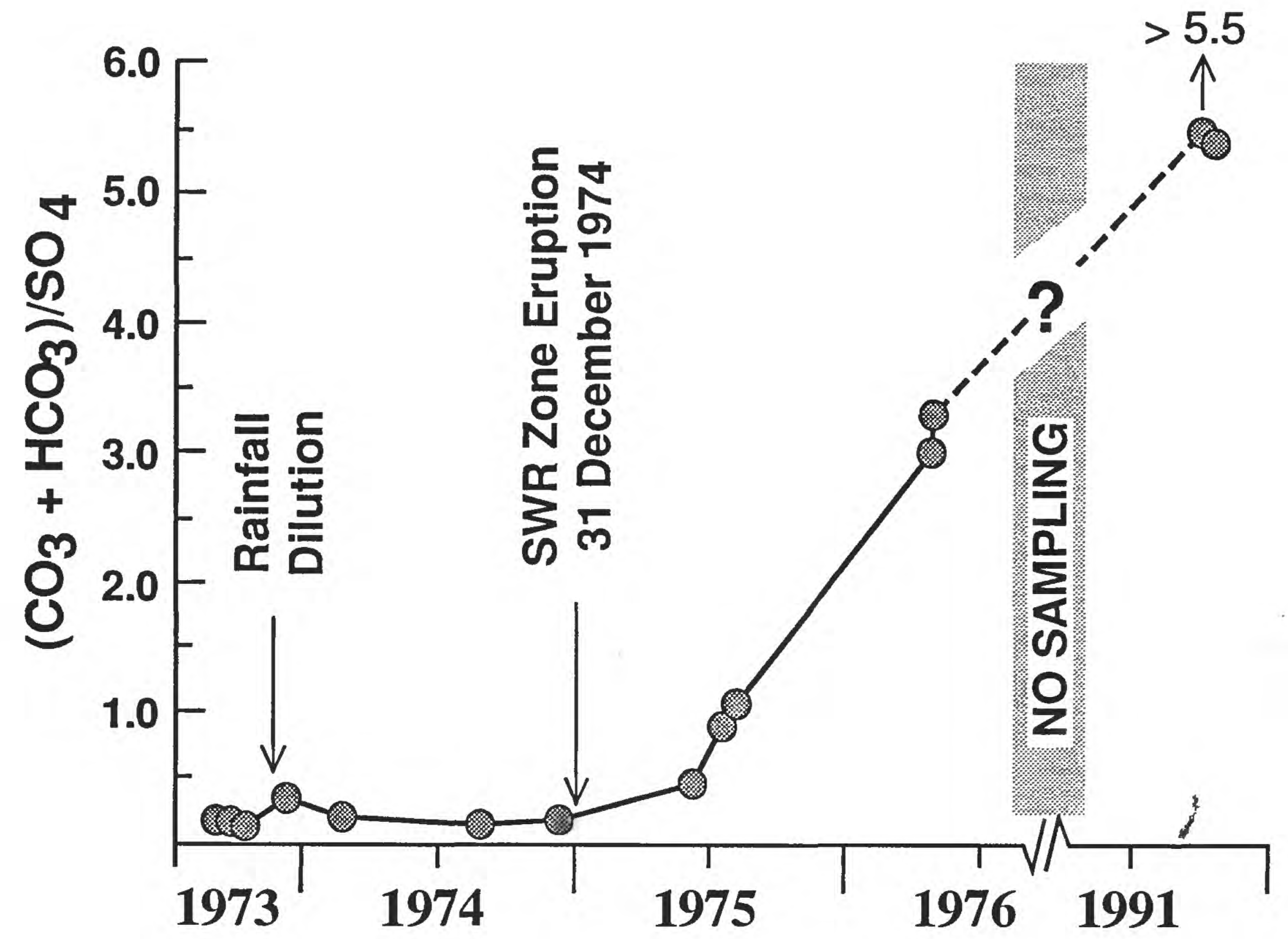

Fig. 15. Temporal variation of the ratio $\left(\mathrm{CO}_{3}+\mathrm{HCO}_{3}\right) / \mathrm{SO}_{4}$ for the Kilauea summit-borehole waters during the same span of time as shown in Figures 13 and 14 (data source: Table 1; concentrations are expressed in meq/L for calculation of ratios). The slope of the curve increases dramatically following the 31 December 1974 eruption in Kilauea's southwest-rift zone (SWR). The two samples collected in August-September 1991 - after a hiatus of 15 years without data-indicate that the borehole waters are still bicarbonate-dominant. 
December 1974 (Fig. 16), the most voluminous event affecting Kilauea's summit and upper southwest-rift zone (SWRZ) since 1919. The eruption itself was brief, lasting only about 16 hours, but dike intrusion and attendant intense seismicity persisted for another week and wedged open the SWRZ by at least 1 meter, thereby facilitating interaction of degassing carbon dioxide with groundwater in the summit region. Following the initial sharp increase during the 31 December 1974 activity, the partial pressure of $\mathrm{CO}_{2}$ then gradually (perhaps exponentially?) decreased, approaching pre-eruption values with our sampling in April 1976 (Fig. 16). Pulse-like increases in $\mathrm{CO}_{2}$ in several geothermal wells associated with rifting and eruption events also have been recognized at Krafla Volcano, Iceland, during the 1975-1982 period (Oskarsson, 1984; Ármannsson and others, 1989, Fig. 7).

The variation in $\mathrm{CO}_{2}$ partial pressure raises the question: If the magmatic degassing associated with the 31 December 1974 eruption perturbed Kilauea's geothermal system, why is there an apparent lack of similar effects during the continuous eruptive activity at Mauna Ulu and the other summit eruptions during the 1974-1976 period (Tilling and others, 1987; Dzurisin and others, 1984). The answer seems to be the unique location of the eruptive outbreak of the December 1974 activity relative to the location of the active part of the summit magma reservoir. The nearest vent fissures for the surface eruptive activity are located less than $1.5 \mathrm{~km} \mathrm{SW}$ of the summit-borehole site (Fig. 16). Thus, magma from the active part of the summit reservoir complex, as indicated by the "magma pressure" or "inflation-deflation" centers, had to move through the region containing the borehole in migrating to the area of eruptive outbreak and further downrift. Such a magma path necessarily would have disrupted the hydrothermal system in the vicinity of the borehole. In contrast, the magma paths to sustain the quasi-steady Mauna Ulu eruption, and the 1974 (July and September) and 1975 summit eruptions merely skirt the borehole site (Fig. 17).

The inferred pulse of $\mathrm{CO}_{2}$ into Kilauea's hydrothermal system during the 31 December activity could account for an increased amount of $\mathrm{HCO}_{3}$ dissolved in the borehole waters, but in itself does not explain the concomitant, abrupt decrease in $\mathrm{SO}_{4}$ concentration at near-constant total solute concentration (Figs. 14 and 18). The close equivalence of $\mathrm{HCO}_{3}$ increase $(9.64 \mathrm{meq} / \mathrm{L})$ and $\mathrm{SO}_{4}$ decrease $(8.54 \mathrm{meq} / \mathrm{L})$ suggests that the two processes may be linked, even though direct evidence is lacking. A similar antipathetic relationship between $\mathrm{HCO}_{3}$ and $\mathrm{SO}_{4}$ was observed by De la Cruz-Reyna and others (1989) for a thermal spring at Tacaná Volcano, Mexico-Guatemala.

The more concentrated Kilauea borehole fluids are almost an order of magnitude undersaturated with respect to gypsum, and at least 5 orders undersaturated with respect to alkali sulfate salts; thus it is unlikely that such an inverse anionic fractionation can be related 


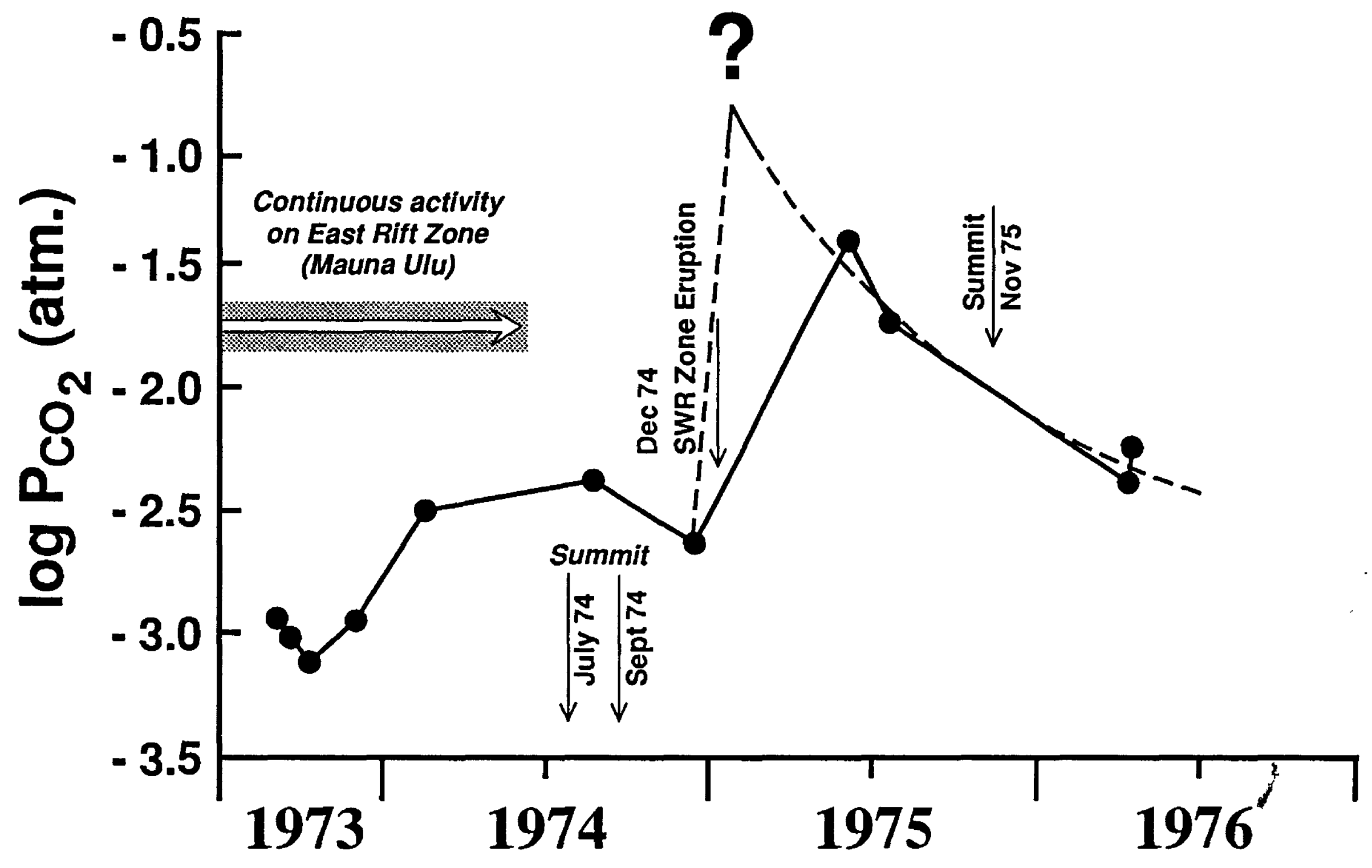

Fig. 16. Temporal variation of partial pressure of $\mathrm{CO}_{2}$ computed from $\mathrm{pH}$, the concentrations of $\mathrm{HCO}_{3}$, and (if determined) $\mathrm{CO}_{3}$ using the analytical expressions given in the WATEQF program (Plummer and others, 1976). The dashed curve for the 1975-1976 period may better represent the actual compositional path, with an initial sharp rise related to magmatic degassing of $\mathrm{CO}_{2}$ during the 31 December 1974 activity, followed by a gradual, possibly exponential, decay (see text). 
to solubility effects even in the unsaturated zone. However, it is possible that physically induced changes in the flow system might have caused simultaneous inverse effects on the primary anionic solute constituents. Rifting and pervasive ground cracking, associated with intense seismicity, accompanied the increase in partial pressure of $\mathrm{CO}_{2}$ during and after the 31 December 1974 outbreak. Such shattering of the ground would have permitted access of additional dissolving fluids to the sulfate efflorescence previously deposited along grain boundaries, cracks, and fissures. At the same time, the ground-shattering processes also would have caused the greatly increased surface area of fresh rock to come in contact with waters newly charged with carbonic acid. According to this scenario, the anion change in the Kilauea borehole fluids reflects a shift in the principal components of volcanic degassing from $\mathrm{SO}_{2}$ to $\mathrm{CO}_{2}$, which on acid hydrolysis and reaction with the rock minerals, primarily plagioclase, produces the major dissolved salts determined. The dominance of sodium in these dissolved salts may indeed reflect the differential precipitation of calcite, which is supersaturated in all the Kilauea borehole waters analyzed.

Interestingly, the heaviest $\delta^{18} \mathrm{O}$ values for borehole waters collected during our entire study were measured for two samples (Table 1; KBW-9 and KBW-10) collected successively after the 31 December 1974 eruption; subsequently, $\delta^{18} \mathrm{O}$ values returned to previous, lighter levels. However, given the analytical uncertainty and the wide variation seen for paired samples collected a few days apart (e.g., Table 1; KBW-10 and -11, and $\mathrm{KBW}-12$ and -13 ), the apparent association of the heaviest $\delta^{18} \mathrm{O}$ values with the $3 y^{2}$ December activity may only be fortuitous. In any case, this association implies a higher temperature fluid-rock reaction, facilitated by new fractures serving as conduits for the $18 \mathrm{O}$-enriched fluids to intercept the borehole.

Sharp decrease in solute concentration after mid-1975. While the 31 December 1974 activity clearly produced a drastic change in the proportion of carbonate to sulfate, it scarcely affected total solute concentration (Fig. 18). After sample KBW-9 (Table 1) was collected in early June 1975, however, the solute concentration of the borehole samples began to decrease sharply, falling from about $45 \mathrm{meq} / \mathrm{L}$ to less than $25 \mathrm{meq} / \mathrm{L}$ in April 1976, primarily reflecting decreases in $\mathrm{SO}_{4}, \mathrm{Cl}, \mathrm{Na}$ and $\mathrm{K}$ (Figs. 13 and 14). The greatest change in total solute occurred between 5 June and 24 July 1975 (Fig. 18). By AugustSeptember 1991, total solute concentration had decreased to less than $17 \mathrm{meq} / \mathrm{L}$ (Table 1), but we have no data on possible temporal variations during the period between the April 1976 and August 1991 samplings.

The cause for this long-term decline in solutes since mid-1975 is not certain. However, we can positively rule out rainfall dilution alone as a factor because rainfall during the period was not unusual (Fig. 18); indeed, during the 7-week period of greatest 


\section{MAGMA PRESSURE CENTERS KILAUEA SUMMIT REGION, DECEMBER 1972 - OCTOBER 1976}

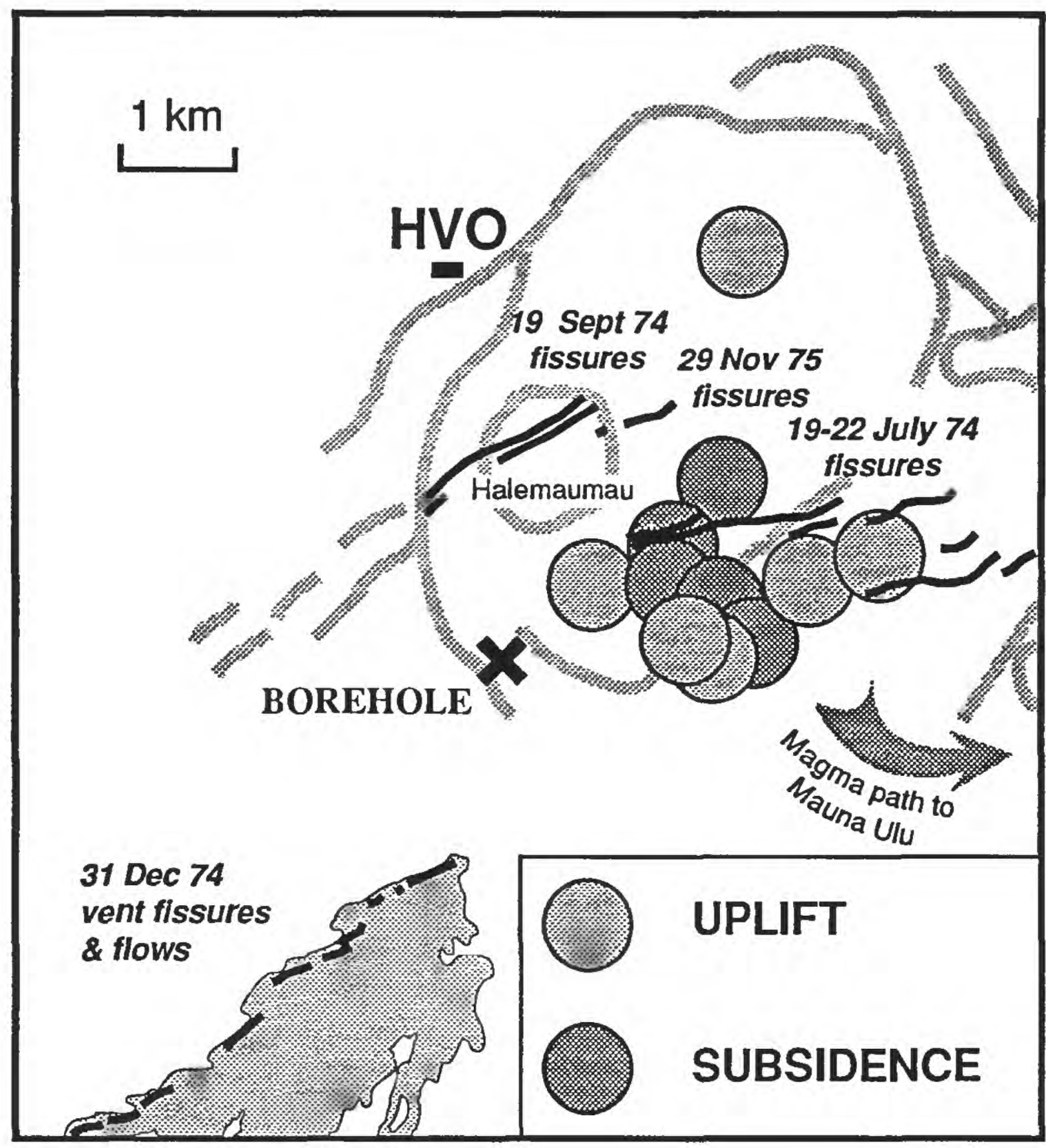

Fig. 17. The location of the summit borehole relative to the vent fissures of eruptions that occurred in the summit region and upper southwest-rift zone of Kilauea Volcano during the period 1972-1976. Shaded arrow (right corner) schematically indicates the magma-supply path to sustain the essentially continuous activity at Mauna Ulu on the east-rift zone during 1972-1974. Also shown are the locations of "magma pressure centers" (also called "inflation-deflation centers") determined by point-source solution of precise-levelling surveys during the period December 1972-October 1976. These centers are inferred to mark the approximate position of Kilauea's subsurface magma reservoir, which during this period varied between 2.4 to $5.1 \mathrm{~km}$ in depth. Data sources: Holcomb (1987, Fig. 12.5) and John J. Dvorak (1992, written communication). 
solute decrease, only $1.9 \mathrm{~cm}$ of rainfall was recorded at $\mathrm{HVO}$ - compared to the $37 \mathrm{~cm}$ of rain in a 3-day period that caused the significant rainfall dilution in December 1973. Nor was there any unusual volcanic or tectonic activity during June-July 1975 at Kilauea that might have perturbed the summit region and triggered the onset of the sharp decline in ion concentration of the hydrothermal system. The only significant volcanic activity at that time was the 5-6 July eruption at the summit of Mauna Loa Volcano, which came back to life after being quiescent for 25 years (Lockwood and others, 1987). However, seismic and geodetic studies showed that the reawakening of Mauna Loa in no way affected Kilauea; moreover, as discussed earlier, hydrogen isotope data (Figs. 11 and 12) preclude any significant mingling of the Kilauea summit-borehole and Mauna Loa summit waters.

Instead, we prefer to interpret the observed dilution trend as simply reflecting the decreased availability of readily leachable alkalis and $\mathrm{SO}_{4}$, which originated in sublimates and encrustations along fractures and vesicles in the host basalt along the water-flow path. We further suggest that the decline of solutes beginning in mid-1975 (Fig. 17), like the change in the carbonate/sulfate ratio (Fig. 14), also is a consequence-albeit expressed a half year later —of the "magmafracting" processes related to the eruptive and intrusive activity on 31 December 1974, which involved the greatest movement of magma and associated ground deformation in Kilauea's southwest-rift zone since 1919. Presumably the increased opening and density of fractures produced by this activity permitted the flushing of accumulated surficial deposits dominated by previous sulfotaric emanations, Another hypothesis, even less amenable to testing, is that the continued settling of the drilling mud in deeper parts of the borehole had greatly reduced permeability by mid-1975; thereafter, the decreased permeability was sufficient to impede, or completely block, the entry of fluids richer in $\mathrm{Cl}, \mathrm{Na}$, and $\mathrm{K}$ into the near-bottom part of the borehole to mix with the water sampled at the top of the water column. This explanation rests on the premise that the post-drilling temperature profile (Fig. 3) is not an equilibrium profile, thereby allowing fluids differing in temperature and composition to enter the borehole at different levels. However, for reasons discussed earlier, we believe that the measured temperature profile, at least to a first approximation, demonstrates thermal equilibrium.

\section{DISCUSSION}

While studies of volcanic gases have been made at Kilauea since the establishment of the Hawaiian Volcano Observatory in 1912 (e.g., Day and Shepherd, 1913; Finlayson and others, 1968; Graeber and others, 1979; Greenland and others, 1985; Greenland, 1987), this study constitutes the only attempt to date to monitor the temporal variation in composition of waters above Kilauea's active magma reservoir. At a number of other 


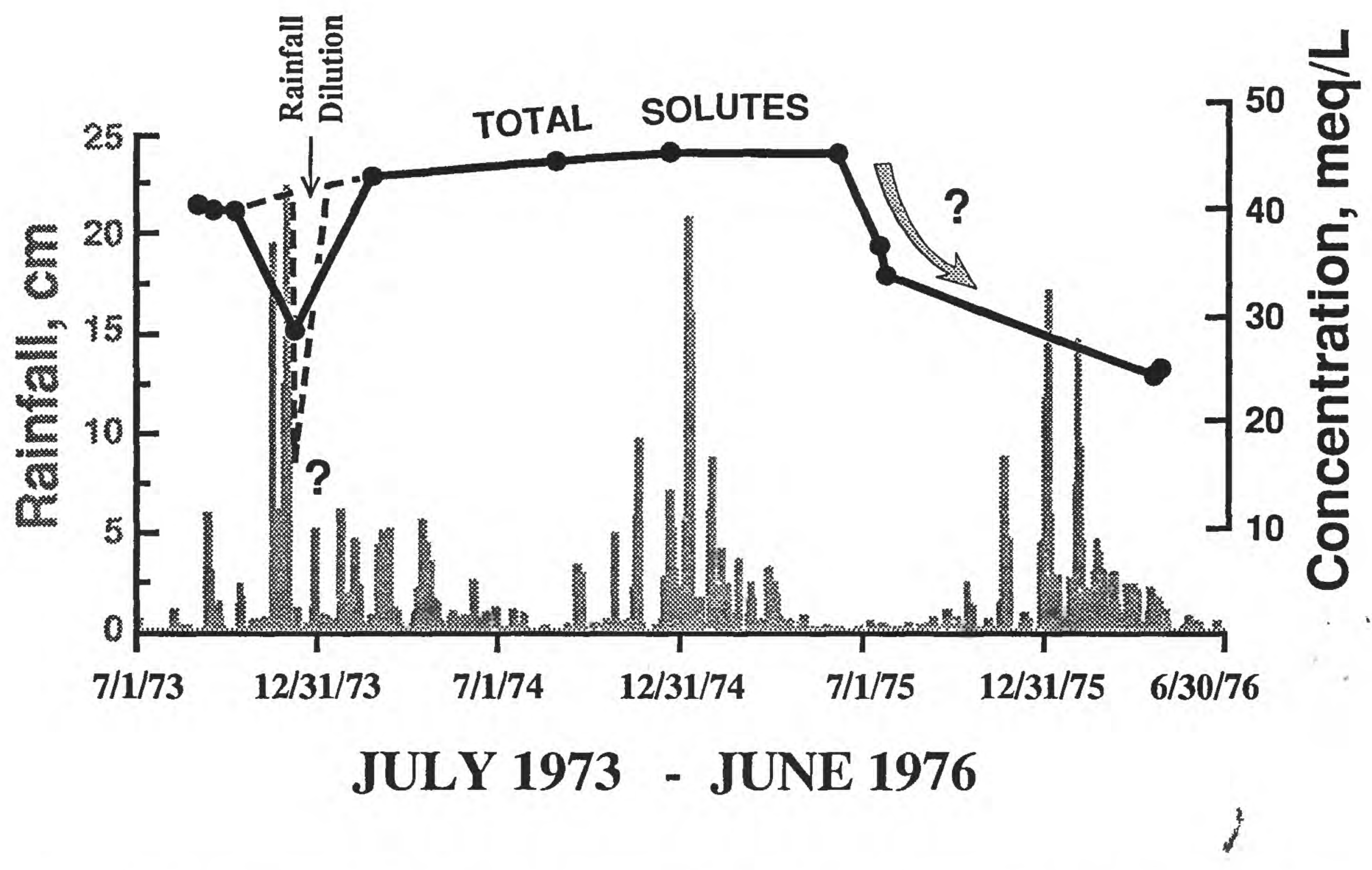

Fig. 18. Temporal variation of total solute concentration for the Kilauea summit-borehole waters and rainfall measured at the Hawaiian Volcano Observatory (HVO), located approximately $3 \mathrm{~km}$ north of the borehole. (Data source: Table 1 and rainfall records of HVO). While the departure from the trend in late 1973 is clearly associated with rainfall dilution (see text), the sharp decrease in concentration after mid-June 1975 cannot be explained by rainfall dilution or volcanic activity; nearly half of this decrease occurred in only about 1.5 months. The two samples collected in August-September 1991, each with total solute concentration less than 17 meq/L (Table 1), may suggest a continuing long-term dilution trend. 
volcanoes, however, the regular sampling and analysis of thermal waters-crater lakes, springs, wells, and surface discharges-has constituted an integral part of volcanic surveillance and/or of geothermal investigations (e.g., Farrar and others, 1985, 1987, 1989; Martini and others, 1991; Fournier, 1989; Nathenson and Thompson, 1990). In this section, we discuss the time-series data for thermal waters from Kilauea summit, mainly within a context of temporal variations observed at some other active volcanoes and recent experimental data on basalt weathering.

\section{Temporal variations in thermal waters at other active volcanoes}

The pulse-like release of $\mathrm{CO}_{2}$ during volcanic activity, as "captured" by the Kilauea summit thermal waters for the 31 December 1974 eruption-intrusion event (Figs. 14-16), was also dramatically shown by monitoring of $\mathrm{CO}_{2}$ in fluids from geothermal wells over a 10-year period at Krafla Volcano, Iceland (Oskarsson, 1984; Ármannsson and others, 1989). $\mathrm{CO}_{2}$ concentration increased from about $0.1 \%$ to more than $2.5 \%$ with eruption onset in December 1975 (after $\sim 250$ years of dormancy), reaching a maximum about 5.5 \% during 1977-78 before beginning a steady decline, interrupted by a secondary maximum in 1980; the variations in $\mathrm{CO}_{2}$ correlate nearly perfectly with elevation changes associated with individual magmatic rifting events (Ármannsson and others, 1989, Fig. 7).

The Krafla case history is especially important because Krafla is also an active basaltic volcano, which, like Kilauea, has a shallow central magma reservoir within it caldera, $2-4 \mathrm{~km}$ below the surface, that feeds all eruptions-within the caldera or along the rift zones. The eruptive dynamics of Krafla are remarkably similar to those of Kilauea despite the considerable difference in their volcano-tectonic settings (Tilling and Dvorak, 1993): Kilauea represents intraplate volcanism, whereas Krafla—straddling the North American and European Plates-represents divergent-plate boundary volcanism. In terms of $\mathrm{CO}_{2}$ degassing during volcanic activity, Kilauea and Krafla also appear to behave similarly.

The temperature, composition, and $\mathrm{pH}$ of waters of crater lakes have been monitored at number of active volcanoes-for example, Taal, Philippines (Alcaraz, 1969); Kelut, Indonesia (Badrudin and Istidjab, 1983; Sudradjat, 1991); Mt. Ruapehu, New Zealand (Giggenbach, 1974; Giggenbach and Glover, 1975); Kusatsu-Shirane, Japan (Takano and Watanuki, 1990); and Poás, Costa Rica (Casertano and others, 1985; Barquero and Fernández, 1990; Rowe and others, 1992a,b). Data for Ruapehu crater-lake waters for the period 1966-73 period provide a good example of temporal variations at an active andesitic volcano. According to Giggenbach and Glover (1975), the variations in $\mathrm{Cl}$ and $\mathrm{Mg}$-rather than in $\mathrm{HCO}_{3}$ and $\mathrm{SO}_{4}$ for Kilauea—are the most diagnostic indicators and 
can best be related to ash eruptions in 1966, 1968, 1969, and 1971 at Ruapehu. An increase in temperature is generally accompanied by increases in $\mathrm{Cl}$ concentration, reflecting magmatic degassing of $\mathrm{HCl}$, and in $\mathrm{Mg}$ concentration, attributed to interaction of lake water with the freshly erupted materials. For example, during the 1971 activity at Mt. Ruapehu, $\mathrm{Mg}$ concentration doubled in four months, and $\mathrm{Cl}$ increased about $40 \%$ over an 8-month period (Giggenbach and Glover, 1975, Fig. 3). For these same two constituents, the Kilauea waters varied quite differently: Despite a temporaray increase of nearly $30 \%$ from $64-70 \mathrm{mg} / \mathrm{L}(12 / 18 / 74)$ to $87 \mathrm{mg} / \mathrm{L}(6 / 05 / 75), \mathrm{Mg}$ concentration showed no net increase during the nearly 7 months following the 31 December 1974 activity; in contrast, $\mathrm{Cl}$ concentration sharply declined by nearly $50 \%$ during the same period and then continued to decline (Table 1).

Time-series compositional data (Thompson, 1990) for new thermal springs formed at Mount St. Helens Volcano, southwestern Washington, after its reawakening in 1980, also show large fluctuations in some chemical constituents, particularly anions. For example, at one spring (Lower Loowit), $\mathrm{Cl}$ concentration decreased, sharply and irregularly, from about 2030 to $379 \mathrm{mg} / \mathrm{L}$ during the period November 1983-August 1984 (Thompson, 1990, Table 2). The Ruapehu and Mount St. Helens examples are given to show that the range and rate of temporal variation in composition observed for the Kilauea thermal waters are not unusual. However, the Mount St. Helens and Ruapehu crater-lake, waters vary more widely in temperature than Kilauea summit waters. At Ruapehu temperature changed more than $25^{\circ} \mathrm{C}$. in only a month, whereas during the entire threeyear period of our study at Kilauea, the temperatures of borehole samples at or near the top of the water column ranged only between $70-79^{\circ} \mathrm{C}$. (Appendix).

It is also instructive to compare the temporal variation of the Kilauea summit waters with time-series compositional data on thermal waters at Campi Flegrei (Phlegraean Fields), Italy (e.g., Martini, 1986; Martini and others, 1991). Campi Flegrei caldera formed about $34 \mathrm{ka}$, followed by numerous smaller eruptions, the most recent being the A.D. 1538 activity that formed Monte Nuovo (Lirer and others, 1987). Systematic study of the thermal springs and fumaroles at Campi Flegrei was intensified following episodes of unrest during 1969-72 and 1982-84 that resulted in $\sim 1.7 \mathrm{~m}$ and $1.8 \mathrm{~m}$ of caldera uplift respectively (Corrado and others, 1976/1977; Dvorak and Mastrolorenzo, 1991). Compared to the Kilauea summit borehole, thermal springs at Campi Flegrei exhibit much less temporal variation, despite longer periods of measurement (Fig. 19). Although minor increases in $\mathrm{HCO}_{3}$ at some springs are attributed to influx of $\mathrm{CO}_{2}$ into shallow aquifers, the geochemical data on Campi Flegrei waters and fumarolic gases appear to be minimally perturbed by the "bradyseismic" crisis of 1982-1984, leading Martini and others (1991) to 


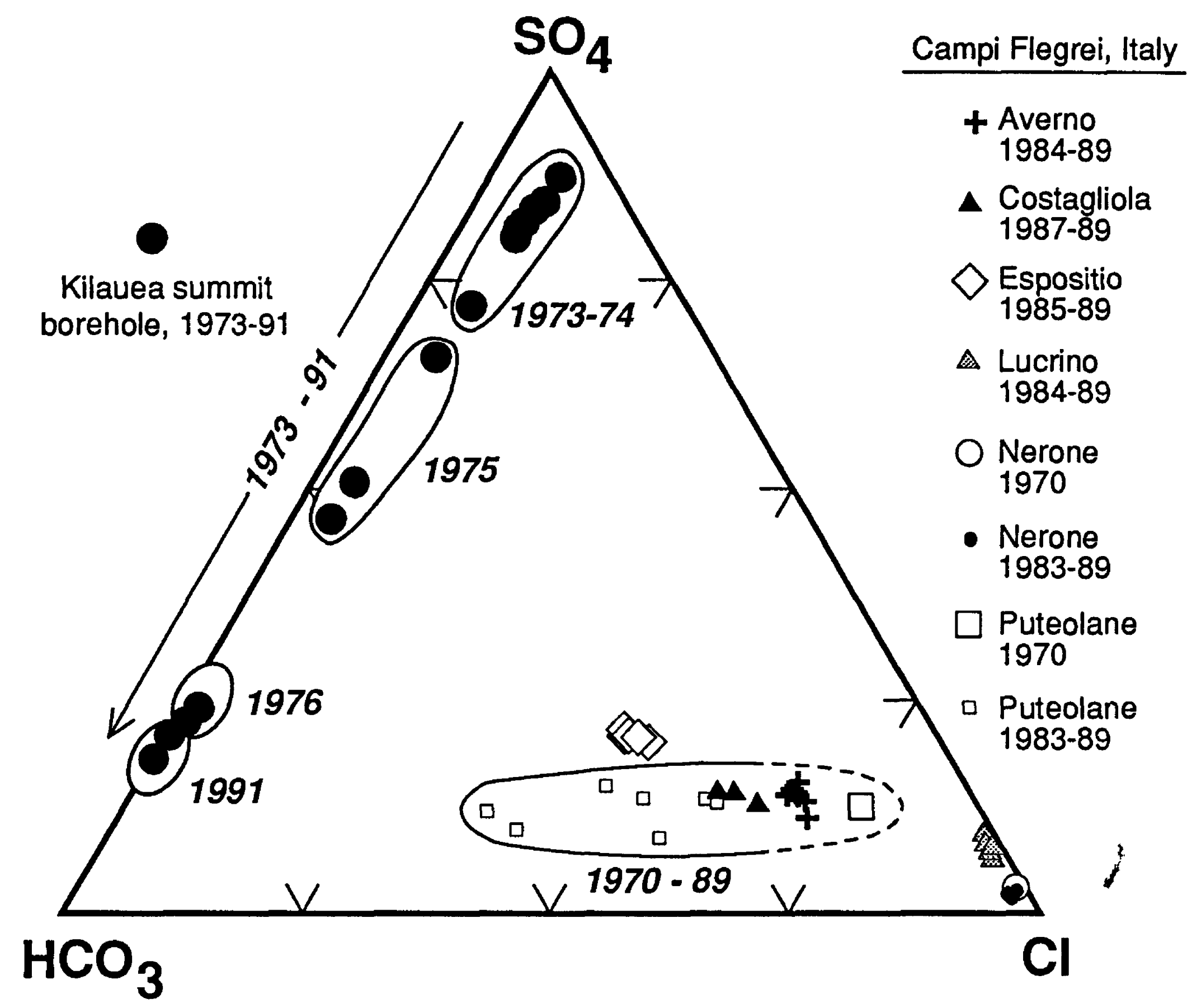

Fig. 19. Comparison of $\mathrm{SO}_{4}-\mathrm{HCO}_{3}-\mathrm{Cl}$ distribution between thermal waters at Kilauea summit and at Campi Flegrei (Phlaegraen Fields), Italy, showing the much greater range and rate of temporal variation for Kilauea. Data points for Kilauea thermal waters are individual samples, and practically the entire range of variation is spanned in only a period of 3 years (1973-1976). In contrast, data points for the various thermal waters at Campi Flegrei caldera are mean annual compositions (computed from 4 or more analyses each year) and, for two sites (Terme Nerone and Terme Puteolane), cover a sampling period of more than 15 years. Only the Terme Puteolane waters show any appreciable variation, especially if extended to the 1970 composition. [Data sources: Table 1, this paper; Martini and others, 1991; Marino Martini, 1992, written communication]. 
conclude that the observed ground deformation is not caused by the intrusion of a magma body. On the other hand, on the basis of geophysical evidence, Dvorak and Mastrolorenzo (1991) argue that hydrothermal processes alone cannot account for the rates of uplift and that the observed ground movements most likely reflect "periodic reactivation," possibly by intrusion of new magma, of a shallow magma system. The causative mechanism of the ground deformation at Campi Flegrei, well documented since 9th century B.C., remains a topic of intense scientific study and debate (see, for example, the studies in Luongo and Scandone, 1991).

\section{Precursors to eruptive activity?}

At some volcanoes, changes in composition of thermal waters have been considered to be precursors to eruptive activity. For example, a six-fold increase in the $\mathrm{SO}_{4}$ concentration at a thermal spring two months prior to the onset of intense seismicity and a small phreatic eruption in May 1986 at Tacaná Volcano (Mexico-Guatemala) was interpreted as a possible precursor of the seismic crisis and ensuing eruptive activity (De la Cruz-Reyna and others, 1989). It should be noted, however, that the study at Tacaná was based on only six months of monitoring (January-June 1986), and began after felt earthquakes in the region were reported in late December 1985. A better documented example, utilizing a data base spanning 25 years, is provided by temporal variations in the composition of the water in Yugama crater lake (Kusatsu-Shirane Volcano, Honshu. Japan). Two months before a phreatic eruption began on 26 October 1982, $\mathrm{SO}_{4}$ concentration increased to $4130 \mathrm{mg} / \mathrm{L}$ (on 26 August 1982), from previous measurements ranging between 1900 and $3130 \mathrm{mg} / \mathrm{L}$ for samples collected during the previous ten years. A more compelling precursory indicator, however, was the accompanying order-ofmagnitude decrease in concentrations of polythionates $\left(\mathrm{S}_{\mathrm{x}} \mathrm{O}_{6}{ }^{2-}\right)$, from values ranging between 620 and $1380 \mathrm{mg} / \mathrm{L}$ to $20 \mathrm{mg} / \mathrm{L}$ or less (Takano, 1987; Takano and Watanuki, 1990). These compositional changes in the crater-lake waters coincided with increased seismicity and the phreatic explosions (Takano and Watanuki. 1990, Fig. 4). Sharp decreases in the concentration of polythionic acids were observed three months prior to the initiation of phreatic eruptions in June 1987 at Poás Volcano, Costa Rica (Rowe and others, 1992b).

Given the infrequent sampling and the correspondingly limited data set obtained for this study, the temporal variations observed for the Kilauea summit waters (Figs. 13-16, 18) obviously provide little basis to discern possible precursors, if any. Besides, it must be remembered that, during the first part of this study (through June 1974), Kilauea was already undergoing long-lived, quasi-steady-state eruptive activity at Mauna Ulu, on its 
upper east-rift zone (Tilling and others, 1987). The remainder of the study period (July 1974-April 1976) was a time of limited visible activity at Kilauea, consisting only of four brief eruptive outbreaks, none of which lasted more than 4 days (Dzurisin and others, 1984): 19-22 July 1974, 19 September 1974, 31 December 1974, and 29 November 1975. Except for the 31 December 1974 activity, which marked the most voluminous eruptive outbreak in Kilauea's southwest rift zone since the 1919-20 activity at Mauna Iki, the other eruptions were confined to the summit caldera. Of these activities, only the 31 December 1974 eruption, and accompanying intrusion and intense seismicity, appeared to have measurably changed the composition of the summit borehole waters (Figs. 14-16). Yet, the two samples collected on 18 December 1974 (KBW-7 and KBW-8, Table 1) showed very little departure from the compositional trends, giving no clear signal of the major eruptive and intrusive activity to take place two weeks later. If the rainfall-dilution effects-seen in the composition of a sample taken two days after intense precipitation-are a measure of the response time to reflect a significant perturbation of Kilauea's hydrothermal system, then a water sample would need to be collected and analyzed every few days to have any hope of using temporal variations in water composition to detect eruption precursors at Kilauea. Realistically, such detection of precursors probably would also require the installation of some type of low-maintenance, near-real-time monitoring device in the borehole to measure temperature, $\mathrm{pH}$, and specific conductivity. Nonetheless, examination of the gradual anionic trends over the entire period of collection of the borehole waters does hint slightly at changes which could be related to increasing magmatic activity. Figure 14 illustrates a 20-25 percent increase in sulfate between initial sampling (September 1973) and the eruption of 31 December 1974. Over the same period, the calculated partial pressure of $\mathrm{CO}_{2}$ increases nearly one-half order of magnitude (Fig. 16), reflecting an increase in bicarbonate and decrease in $\mathrm{pH}$. As discussed earlier, both these indicators can be related to magmatic degassing.

\section{Bearing on weathering of basalt}

The Kilauea summit borehole waters have displayed temporal variations in major solute composition over the period of their collection which have significant implications for the weathering of basalt. For both the major cations (Figs. 7 and 9) and major anions (Figs. 8 and 10), the time-series trends point to the compositional fields for groundwaters associated with the normal weathering of basaltic host rocks. It should be emphasized, however, that these ternary variation diagrams only compare proportions of principal cations and anions and do not take into account major differences in concentration, especially between the Kilauea summit borehole waters and other non-thermal 
groundwaters associated with weathering. The Kilauea samples collected in 1976 and 1991 have substantially lower total solute concentrations than the fluids collected earlier; they most closely approach the nearby summit (Wright Road) non-thermal waters as well as the average major-solute compositions for non-thermal waters in basaltic terranes (Figs 7-10). This difference is almost entirely attributable to decrease in solute sodium sulfate with time. Are these observations merely fortuitous, or do they suggest that, regardless of temporal perturbations related to the dynamics of an active volcanic system, the reaction of meteoric waters with basaltic rocks approaches steady state in terms of solute proportions, at least for the major cations? According to the scheme of Giggenbach (1992), the temperature and anion-concentration data (Appendix and Fig. 8) suggest that the summitborehole waters are becoming more "peripheral" to Kilauea's hydrothermal system, as characterized by declining temperatures and relative increase of $\mathrm{HCO}_{3}$.

Other studies are pertinent to the above question. Utilizing chemical analysis of both solids and interstitial fluids, Hay and Jones (1972) have demonstrated that the weathering of Hawaiian basaltic tephra is a function of both climate and age, but the quantitative relationship between water composition and leaching rate has remained uncertain. Taking analyses of interstitial waters in the Pahala Ash $(\sim 10-25 \mathrm{ka})$ and the Keanakakoi Formation ( A.D. 1790-1820), and assuming $10 \mathrm{ka}$ to be age of the top of the Pahala Ash, Hay and Jones (1972) calculated leaching rates $\left(\mathrm{g} / \mathrm{cm}^{2} / 10^{4} \mathrm{yrs}\right)$ for selected chemical constituents: for example, 39 for $\mathrm{SiO}_{2}$ and 7.1 for $\mathrm{Ca}$. However, calculationd based on the compositional differences between fresh and weathered host rock for the same two constituents yielded leaching rates about twice as fast.

More recent studies of silicate rock weathering [see examples in Colman and Dethier (1986), or the summary of Brantley (1992)] have documented orders of magnitude differences in field and laboratory rates related primarily to wetted surface variations, and White and others (1992) have shown a progressive decrease in rates of silicate weathering in soil chronosequences on granite. Hay and Jones (1972) attributed their discrepancies between solution and solid leaching calculations principally to uncertainties in rates of infiltrations and fluid flow, as well as surface area effects, but concluded that a constant proportion of silica and cations reflected the steady-state alteration of primary silicates. The enormous variation and dramatic changes in fracture density makes it impossible to estimate the total leached rock surface or reaction time represented by the Kilauea summit borehole waters, but the approach to cation proportions representative of basaltic rock weathering elsewhere is consistent with these findings.

The recent experimental study of White and Hochella (1992) shows that the weathering of basalt flows may be conditioned by cooling history and short-term, subaerial 
weathering immediately after eruption. They compared the surface chemistries of fresh (i.e., not rained upon) basalt flows-erupted at Kilauea during 1987-1990 and at Krafla (Iceland) during 1980 - with those of compositionally comparable, but older flows exposed to subaerial weathering over time scales of years to millennia. Surprisingly, the surfaces of the unweathered flows are greatly enriched in $\mathrm{Al}, \mathrm{Mg}, \mathrm{Ca}$, and $\mathrm{F}$ because of the formation of refractory fluoride compounds, but are depleted in $\mathrm{Si}$ and $\mathrm{Fe}$ from the volatilization of $\mathrm{SiF}_{4}$ and $\mathrm{FeF}_{3}$ during cooling of the flow. However, White and Hochella's (1992, Fig. 7) data for repeated samplings of the 1987 Kilauea flow also indicated that, in less than a year, the initially fluoride-enriched surface is leached to give a $\mathrm{SiO}_{2}$-dominant surface characteristic of older and weathered historical and prehistoric flows at Kilauea and Mauna Loa Volcanoes (Farr and Adams, 1984; Curtiss and others, 1985). These results allow the estimation of "maximum leach depths" for the fluoride-enriched surface as high as about 50 microns during the first year of weathering of Hawaiian basalts (White and Hochella, 1992, Table 4). Although such short-term, apparently rapid subaerial leaching of fluoride compounds cannot be directly extrapolated to longer-term subsurface leaching or mineral-deposition processes during long-term weathering, the findings of White and Hochella (1992) at least imply that significant rock-water interactions may occur at rates much faster than generally supposed. In any case, frequently recurring ground breakage associated with Kilauea's frequent volcanic activity must in turn create a virtually endless supply of fresh rock surfaces to promote rock-water interactions, thereby facilitating extensive leaching or mineral-deposition process, subaerial or subsurface.

\section{Directions for future research}

By good fortune, our meager time-series data on the evolution of the summit borehole waters managed to "capture" both short-term and longer temporal variations in composition during the 1973-1976 observation period. While necessarily qualitative, our interpretation of these variations clearly indicates that the behavior of Kilauea's summit hydrothermal system reflects the complex and quick-response interplay between recharge (rainfall) and eruptive activity. It is also abundantly clear that this study has generated more questions than answers. To adequately address these questions, an in-depth investigation of the hydrogeology of Kilauea Volcano-one of the most active in the world-is sorely needed.

Relevant to the findings of this study, several broad approaches for future research are obvious, including:

To better document and interpret rainfall-dilution effects on water composition, improved characterization of the recharge pattern of Kilauea summit and adjacent areas 
of Mauna Loa will be essential. At present, the only information on the distribution of mean annual rainfall on the Island of Hawaii is based on records for the period 1931-55 (Davis and Yamanaga, 1973, Fig. 1), and to date the rainfall-measurement stations in the region of interest have been few or entirely lacking. However, recent studies begun by the USGS have established more than 50 rain collectors (elevations 0 to $>4,100 \mathrm{~m}$ ) covering Kilauea Volcano and the flank of Mauna Loa Volcano, and studies of the isotopic variation of precipitation collected at these sites are underway (Scholl and others, 1992, 1993).

- To more quantitatively analyze the compositional variations in the thermal waters above Kilauea's magma reservoir, data on the nature and emission rate of gases from eruptive vents and fumaroles also must be considered. Because systematic volcanic gas studies were not conducted at Kilauea until the early 1980s (see, for example, Gerlach and Graeber, 1985; Greenland and others, 1985; Greenland, 1987), gas data corresponding to our 1973-1976 time-series data for waters do not exist.

- To determine the composition of water in the deeper and hotter parts of the summit borehole (see Fig. 3), samples need to be collected more than $30 \mathrm{~m}$ below the top of the water column. The collection and analysis of deeper samples are essential to extend and to test the findings of this study, based only on data for waters at or near the top of the water column. Unfortunately, upon completion of the borehole in 1973, the drilling, mud was not flushed from the hole, ultimately becoming impenetrable to sampling and other tools. Thus, it will be necessary to clean out the hole before collection of deep water samples can be attempted.

- To more quantitatively describe and explain the rapid decrease in solute concentration during 1975-1976 as well as the slower decline since then, detailed studies-field and experimental - of the rates of leaching, the temperature-pressure-saturation conditions governing formation of sublimates and encrustations on fracture surfaces, the effective permeability of the host basalt, and other factors pertinent to rock-water interactions along the fluid-flow paths. Specifically, because the observed sharp decline in solutes during 1975-1976 principally reflects the rapid loss of $\mathrm{Na}, \mathrm{K}$, and $\mathrm{SO}_{4}$, the kinetics of dissolution and precipitation of alkali sulfate salts (e.g., thenardite) need to be better determined for the physico-chemical conditions of Kilauea's hydrothermal system.

- To provide regional context for the geothermal systems in Kilauea's east-rift zone, some of which are currently being exploited and developed, it is imperative to know the fluid-flow patterns for the entire volcano, from its summit to the coast. Because Kilauea's summit magma reservoir is the ultimate heat engine and supplier of magma intruded into the rift zones, it makes good scientific-and perhaps economic and 
environmental-sense to refine our knowledge of the magmatic and hydrologic connection between the volcano's summit region and its rift zones. Decades of systematic study have provided a reasonably good model of Kilauea's magmatic "plumbing system" (Tilling and Dvorak, 1993), but its hydrologic plumbing system is still incompletely characterized and poorly understood.

Comprehensive hydrogeologic studies at Kilauea have been proposed, but not funded, since the late 1960s, but it was not until 1991 that the U.S. Geological Survey was able to initiate a modest-scale research effort, in cooperation with the University of Hawaii and Los Alamos National Laboratories, to better understand the hydrogeologic framework of Kilauea. Work is underway and we anticipate that new insights will be forthcoming concerning the nature and workings of the fluid envelope surrounding an active basaltic magma system (Moore and Kauahikaua, 1993).

\section{ACKNOWLEDGMENTS}

The analytical data reported here represent the collective efforts by many individuals and organizations since the initiation of this study nearly 20 years ago (!), and to them we want to express our sincere, if somewhat belated, thanks. Charles J. Zablocki (formerly USGS, now retired) and Robert O. Fournier (USGS, Menlo Park) assisted with many of the physically strenuous sampling runs. Our colleagues at the Water Resources Division field of fices-Hideo Gushiken (Hilo, Hawaii) and Johnston J.S. Yee (Honolulu, Hawaii) - and Donald M. Thomas at the University of Hawaii (Hawaii Institute of Geophysics, Honolulu) provided many of the non-borehole samples as well as the relevant field and analytical information about them. John P. Lockwood (USGS, Hawaiian Volcano Observatory) collected the water samples from the summit of Mauna Loa Volcano. The cooperation and assistance of George V. Keller, John C. Murray, and Cathy Skokan-formerly or presently at the Colorado School of Mines-throughout our study are very much appreciated. We also wish to thank Shirley Rettig (formerly USGS, now retired), Theresa Presser (USGS, Menlo Park), Roy J. Knight and Hugh Millard (USGS, Denver), Tyler Coplen (USGS, Reston), L. Douglas White and Mark Huebner (USGS, Menlo Park) for chemical and isotopic analyses; George Keller also made available some unpublished analytical data obtained by Skyline Labs, Inc., Wheat Ridge, Colorado. Steve E. Ingebritsen and Martha Scholl (USGS, Menlo Park) kindly allowed us to include in this study their unpublished data on the 1991 summit-borehole samples. Finally, an earlier version of this manuscript was critically reviewed by our USGS colleagues Robert $O$. Fournier and Cathy Janik, who asked penetrating questions, provided perceptive insights, 
and offered constructive comments and valuable suggestions toward its improvement. To them we give special thanks, but we alone bear responsibility for any errors in the treatment and interpretation of the data. 


\section{REFERENCES}

Alcaraz, A., 1969, Is Taal Volcano Drawing Closer to Another Eruptive Activity?: The COMVOL Letter (Philippine Commission on Volcanology), v. 3, no. 5 (Sept.-Oct. 1969), $10 \mathrm{p}$.

Anonymous, 1970, Inventory of Basic Water Resources Data: Island of Hawaii: Division of Water and Land Management, Department of Land and Natural Resources, State of Hawaii, Honolulu, 188 p.

Ármannsson, Halldór, Benjamínsson, Jón, and Jeffrey, A.W.A., 1989, Gas changes in the Krafla geothermal system, Iceland: Chemical Geology, v. 76, p. 175-196.

Arnórsson, S., and Sigurdsson, S., 1974, The utility of waters from high-temperature areas in Iceland for space heating as determined by their chemical composition: Geothermics, v. 3, no. 4, p. 127-141.

Arnórsson, S., 1970, Geochemical studies of thermal waters in the Southern Lowlands of Iceland, in U.N. Symposium on the Development and Utilization of Geothermal Resources, Pisa, Italy, v. 2, Part 1, p. 547-552.

Arnórsson, S., 1979, Hydrochemistry in geothermal investigations in Iceland: Techniques and applications: Nordic Hydrology, v. 20, 191-224.

Arnórsson, Stefán, Gunnlaugsson, Einar, and Svavarsson, Hördur, 1983, The chemistry, of geothermal waters in Iceland. II. Mineral equilibria and independent variableb controlling water compositions: Geochimica Cosmochimica Acta, v. 47, p. 547-566.

Badrudin, M., and Istidjab, M., 1983, Penggunaan unsur indikator kimia dalam hubungannya dengan kegiatan vulkanik di danau kawah G. Kelut, Jawa Timur: Volcanological Survey of Indonesia, Bandung, unpublished report, 21 p. [in Indonesian].

Barquero, J., and Fernández, E., 1990, Erupciones de gases and sus consecuencias en el Volcán Poás, Costa Rica: Boletín de Vulcanología, no. 21, p.13-18. [In Spanish].

Bodine, M. W., Jr., and Jones, B.F., 1986, The salt norm: A quantitative chemicalmineralogical characterization of natural waters: U.S. Geological Survey, Water Resources Investigations Report 86-4086, 130 p.

Brantley, S.L., 1992, Kinetics of dissolution and precipitation-Experimental and field results, in Kharaka, Y.K., and Maest, A.S., editors, Proceedings of the 7th International Symposium on water-rock interaction, Park City, Utah, 13-18 July 1992: A.A. Balkema, Rotterdam, The Netherlands, v. 1, p. 3-6. 
Casadevall, T.J., and Dzurisin, Daniel, 1987, Stratigraphy and petrology of the Uwekahuna Bluff section, Kilauea caldera, in Decker, R.W., Wright, T.L., and Stauffer, P.H., editors, 1987, Volcanism in Hawaii: U.S. Geological Survey Professional Paper 1350, volume 1, p. 351-375.

Casertano, L., Borgia, A., Cigolini, C., Morales, L.D., Montero, W., Gomez, M., and Fernandez, J.F., 1985, Investigaciones geofísicas y características geoquímicas de las aguas hidrotermales: Volcán Poás, Costa Rica: Geofísica Internacional, v. 24, no. 2, p. 315-332.

Clague, D.A., and Dalrymple, G.B., 1987, The Hawaiian-Emperor volcanic chain: Part I. Geologic evolution, in Decker, R.W., Wright, T.L., and Stauffer, P.H., editors, 1987, Volcanism in Hawaii: U.S. Geological Survey Professional Paper 1350, volume 1, p. 5-54.

Clague, D.A., and Dalrymple, G.B., 1989, Tectonics, geochronology, and origin of the Hawaiian-Emperor volcanic chain, in Winterer, E.L., Hussong, D.M., and Decker, R.W., editors, The Eastern Pacific Ocean and Hawaii: Boulder, Colorado, Geological Society of America, The Geology of North America, v. N, Chapter 12 (The Hawaiian-Emperor Chain), p. 188-217.

Colman, S.M., and Dethier, D.P., editors, 1986, Rates of chemical weathering of rocks and minerals: Academic Press, New York, 603 p.

Coplen, T.B., 1973, A double-focusing, double-collecting mass spectrometer for light stable isotope ratio analysis: International Journal of Mass Spectrometry Ion Physics, v. 11, p. $37-40$.

Corrado, G., Guerra, I., Lo Basico, A., Luongo, G., and Rampoldi, R., 1967/1977, Inflation and microearthquake activity of Phlegraean Fields, Italy: Bulletin Volcanologique, v. 40, p. 169-188.

Craig, Harmon, 1961, Isotopic variations in meteoric waters: Science, v. 133, p. 17021703.

Curtiss, B., Adams, J.B., and Ghiorso, M.S., 1985, Origin, development and chemistry of silica-alumina rock coatings from the semi-arid regions of the island of Hawaii: Geochimica et Cosmochimica Acta, v. 49, p. 49-56.

Dalrymple, G.B., Silver, E.A., and Jackson, E.D., 1973, Origin of the Hawaiian Islands: American Scientist, v. 61, p. 294-308.

Davis, D.A., and Yamanaga, George, 1973, Water Resources Summary, Island of Hawaii: U.S. Geological Survey Report R47, 42 p. [Prepared in cooperation with Division of Water and Land Development, Department of Land and Natural Resources, State of Hawaii.] 
Day, A.L., and Shepherd, E.S., 1913, L'eau et les gaz magmatiques: Comptes Rendu Seances de l'Academie des Sciences, v. 157, p. 1-7.

De la Cruz-Reyna, S., Armienta, M.A., Zamora, V., and Juárez, F., 1989, Chemical changes in spring waters at Tacaná volcano, Chiapas, Mexico: A possible precursor of the May 1986 seismic crisis and phreatic explosion: Journal of Volcanology and Geothermal Research, v. 38, p. 345-353.

Delfin, F.G., Jr., Sussman, D., Ruaya, J.R., and Reyes, A.G., 1992, Hazard assessment of the Pinatubo volcanic-geothermal system: Clues prior to the June 15, 1991 eruption: Transactions, Geothermal Resources Council, v. 16, p. 519-527.

Dodge, F.C.W., Millard, H.T., Jr., and Elsheimer, H.N., 1982, Compositional variations and abundances of selected elements in granitoid rocks and constituent minerals, central Sierra Nevada batholith, California: U.S. Geological Survey Professional Paper 1248, 24 p.

Dvorak, J.J., and Mastrolorenzo, Giuseppe, 1991, The mechanisms of recent vertical crustal movements in Campi Flegrei caldera, southern Italy: Geological Society of America Special Paper 263, 47 p.

Dzurisin, Daniel, Koyanagi, R.Y., and English, T.T., 1984, Magma supply and storage at Kilauea Volcano, Hawaii, 1956-1983: Journal of Volcanology and Geothermal Research, v. 21, p. 177-206.

Farr, T.G., and Adams, J.B., 1984, Rock coatings in Hawaii: Bulletin, Geological Society of America, v. 95, p. 1077-1083.

Farrar, C.D., Sorey, M.L., Rojstaczer, S.A., Janik, C.J., Mariner, R.H., Winnett, T.L., and Clark, M.D., 1985, Hydrologic and geochemical monitoring in Long Valley caldera, Mono County, California, 1982-84: U.S. Geological Survey WaterResources Investigations Report 85-4183, 137 p.

Farrar, C.D., Sorey, M.L., Rojstaczer, S.A., Janik, C.J., Mariner, R.H., Winnett, T.L., and Clark, M.D., 1987, Hydrologic and geochemical monitoring in Long Valley caldera, Mono County, California, 1985: U.S. Geological Survey Water-Resources Investigations Report 87-4090, 71 p.

Farrar, C.D., Sorey, M.L., Rojstaczer, S.A., Steinemann, A.C., and Clark, M.D., 1989, Hydrologic and geochemical monitoring in Long Valley caldera, Mono County, California, 1986: U.S. Geological Survey Water-Resources Investigations Report 89-4033, 69 p.

Finlayson, J.B., Barnes, I.L., and Naughton, J.J., 1968, Developments in volcanic gas research in Hawaii, in The Upper Crust and Upper Mantle of the Pacific Area: American Geophysical Union, Geophysical Monograph, v. 12, p. 428-438. 
Fournier, R.O., 1987, Conceptual models of brine evolution in magmatic-hydrothermal systems, in Decker, R.W., Wright, T.L., and Stauffer, P.H., editors, Volcanism in Hawaii: U.S. Geological Survey Professional Paper 1350, Volume 2, Chapter 55, p. 1487-1506.

Fournier, R.O., 1989, Geochemistry and dynamics of the Yellowstone National Park hydrothermal system: Annual Reviews Earth and Planetary Science, v. 17, p. 13-53. Fournier, R.O., 1990, The interpretation of $\mathrm{Na}-\mathrm{K}-\mathrm{Mg}$ relations in geothermal waters: Geothermal Resources Council Transactions, v. 14, part. II, p. 1421-1425.

Fritz, P., Cherry, J.A., Weyer, K.U., and Sklash, M., 1976, Storm runoff analyses using environmental isotopes and major ions, in Interpretation of Environmental Isotope and Hydrochemical Data in Groundwater Hydrology: International Atomic Energy Agency, Vienna, Austria, p. 111-130.

Gerlach, T.M., and Graeber, E.J., 1985, Volatile budget of Kilauea Volcano: Nature, v. 313, p. 273-277.

Giggenbach, W.F., 1974, The chemistry of the crater lake on Mt. Ruapehu (New Zealand) during and after the 1971 active period: New Zealand Journal of Science, v. 17, p.33-45.

Giggenbach, W.F., 1988, Geothermal solute equilibria. Derivation of Na-K-Mg-Ca geoindicators: Geochimica Cosmochimica Acta, v. 52, p. 2749-2765.

Giggenbach, W.F., 1992a, Chemical techniques in geothermal exploration, in D'Amoref Franco, co-ordinator, Applications of geochemistry in geothermal reservoir development: UNITAR/UNDP Centre on Small Energy Sources, Rome, Italy, p. 119-144.

Giggenbach, W.F., 1992b, Isotopic shifts in waters from geothermal and volcanic systems along convergent plate boundaries and their origin: Earth and Planetary Science Letters, v. 113, p. 495-510.

Giggenbach, W.F., and Glover, R.B., 1975, The use of chemical indicators in the surveillance of volcanic activity affecting the crater lake on Mt. Ruapehu, New Zealand: Bulletin Volcanologique, v. 39, no. 4, p. 70-81.

Giggenbach, W.F., Garcia P., N, Londoño C., L., Rodriguez, V., Rojas G., N., and Calvache, M.L., 1990, the chemistry of fumarolic vapor and thermal-spring discharges from the Nevado del Ruiz volcanic-magmatic-hydrothermal system, Colombia: Journal of Volcanology and Geothermal Research, v. 42, p. 13-39.

Gislason, S.R., and Eugster, H.P., 1987, Meteoric water-basalt interactions. II: A field study in N.E. Iceland: Geochimica et Cosmochimica Acta, v. 51, p. 2841-2855. 
Graeber, E.J., Modreski, P.J., and Gerlach, T.M., 1979, Compositions of gases collected during the 1977 east rift eruption, Kilauea, Hawaii: Journal of Volcanology and Geothermal Research, v. 5, p. 337-344.

Greenland, L.P., 1987, Hawaiian eruptive gases, in Decker, R.W., Wright, T.L., and Stauffer, P.H., editors, Volcanism in Hawaii: U.S. Geological Survey Professional Paper 1350, volume 1, chapter 28, p. 759-770.

Greenland, L.P., Rose, W.I., and Stokes, J.B., 1985, An estimate of gas emissions and magmatic gas content from Kilauea Volcano: Geochimica et Cosmochimica Acta, v. 49, p. 125-129.

GVN, 1994, Kilauea: Bulletin of the Global Volcanism Network (GVN), v. 19, no. 9, p. 14.

Hay, R.L., and Jones, B.F., 1972, Weathering of basaltic tephra on the Island of Hawaii: Bulletin, Geological Society of America, v. 83, p. 317-332.

Heliker, C.C., and Wright, T.L., 1991, The Pu'u O'o-Kupaianaha eruption of Kilauea: Eos, Transactions, American Geophysical Union, v. 72 , no. 47 , p. 521, 526, 530.

Hem, J.D., 1989, Study and interpretation of the chemical characteristics of natural water:

U.S. Geological Water-Supply Paper 2254 (Third Edition), 263 p.

Holcomb, R.T., 1987, Eruptive history and long-term behavior of Kilauea Volcano, in Decker, R.W., Wright, T.L., and Stauffer, P.H., editors, Volcanism in Hawaii U.S. Geological Survey Professional Paper 1350, Volume 1, Chapter 12, p. 261350 .

Ingebritsen, S.E., and Scholl, M.A., 1993, The hydrogeology of Kilauea Volcano: Geothermics, v. 22, no. 4, p. 255-270.

Jackson, D.B., and Kauahikaua, Jim, 1990, The high-level water table beneath Kilauea Volcano, Hawai'i [abstract]: Transactions, American Geophysical Union, Eos, v. 71 , no. 43, p. 1676.

Jackson, D.B., and Lenat, J.-F., 1989, High-level water tables on Hawaiian type volcanoes and intermediate depth geoelectric structures, Kilauea Volcano, Hawaii and Piton de la Fournaise Volcano, Isle de la Reunion [abstract]: Abstracts Volume, IAVCEI General Assembly on Continental Magmatism, 25 June-1 July 1989, Santa Fe, New Mexico: Bulletin 131, New Mexico Bureau of Mines \& Mineral Resources, p. 142.

Jones, B.F., 1966, Geochemical evolution of closed basin water in the Western Great Basin, in Rau, J.L., editor, Second Symposium on Salt, Northern Ohio Geological Society, v. 1, p. 181-200. 
Jones, B.F., Vandenburgh, A.S., Truesdell, A.H., and Rettig, S.L., 1969, Interstitial brines in playa sediments: Chemical Geology, v. 4, p. 253-262.

Jones, B.F., and Bodine, M.W., Jr., 1987, Normative salt characterization of natural waters, in Fritz, P., and Frape, S.K., eds., Saline water and gases in crystalline rocks: Geological Association of Canada Special Paper 33, p. 5-18.

Jones, B.F., Hanor, J.S., and Evans, W.R., 1994, Sources of dissolved salts in the central Murray Basin, Australia: Chemical Geology, v. 111, p. 135-154.

Kauahikaua, J., 1993, Geophysical characteristics of the hydrothermal systems of Kilauea Volcano, Hawai'i: Geothermics, v. 22, no. 4, p. 271-299.

Keller, G.V., 1974, Drilling at the summit of Kilauea Volcano: An unpublished report prepared for the National Science Foundation, 15 March 1974, 45 double-spaced typescript pages.

Keller, G.V., Grose, T.L., Murray, J.C., and Skokan, C.K., 1979, Results of an experimental drill hole at the summit of Kilauea Volcano, Hawaii: Journal of Volcanology and Geothermal Research, v. 5, p. 345-385.

Keller, G.V., Murray, J.C., and Towle, G.H., 1974a, Geophysical logs from the Kilauea geothermal research drill hole: Proceedings, Society of Professional Well Log Analysts, June 2-5, 1974, v. 15. p. 1-17.

Keller, G.V., Murray, J.C., Skokan, J.J., and Skokan, C.K., 1974b, CSM research drill . hole at summit of Kilauea volcano: Mines Magazine, v. 64, no. 5, p. 14-18.

Keller, G.V., Murray, J.C., Zablocki, C.J., Tilling, R.I., Peterson, D.W., and Christiansen, R.L., 1976, Deep research drillhole at Kilauea Volcano, Hawaii-Summary, in Halbouty, M.T., Maher, J.C., and Lian, H.M., eds., Proceedings, Circum-Pacific Energy and Mineral Resources Conference, Honolulu, Hawaii, August 1974: Memoir 25, American Association of Petroleum Geologists, p. 154155.

Kendall, Carol, and Coplen, T.B., 1985, Multi-sample conversion of water to hydrogen by zinc for stable isotope determination: Analytical Chemistry, v. 57, no. 7, p. 14371440.

Kroopnick, P.M., Buddemeier, R.W., and Thomas, D.M., 1978, Hydrology and geochemistry of a Hawaiian geothermal system: HGP-A: Hawaii Institute of Geophysics Technical Report HIG-78-6, 64 p.

Lirer, L., Luongo, G., and Scandone, R., 1987, On the volcanological evolution of Campi Flegrei: Eos, Transactions of the American Geophysical Union, v. 68, p. 226-234. 
Lockwood, J.P., Dvorak, J.J., English, T.T., Koyanagi, R.Y., Okamura, A.T., Summers, M.L., and Tanigawa, W.R., 1987, Mauna Loa 1974-1984: A decade of intrusive and extrusive activity, in Decker, R.W., Wright, T.L., and Stauffer, P.H., editors, Volcanism in Hawaii: U.S. Geological Survey Professional Paper 1350, Volume 1, Chapter 19, p. 537-570.

Luongo, G., and Scandone, R., editors, 1991, Campi Flegrei Special Issue: Journal of Volcanology and Geothermal Research, v. 48, nos. 1/2, p. 1-227.

Marini, L., Agostini, A., Cioni, R., Guidi, M., and Leon, O., 1991, Guagua Pichincha volcano, Ecuador: fluid geochemistry in volcanic surveillance: Journal of Volcanology and Geothermal Research, v. 46, p. 21-35.

Martini, Marino, 1986, Thermal activity land ground deformation at Phlegrean Fields, Italy: Precursors of eruptions or fluctuations of quiescent volcanism? A contribution of geochemical studies: Journal of Geophysical Research, v. 91, no. B12, p. $12,255-12,260$.

Martini, Marino, Giannini, Luciano, Buccianti, Antonella, Prati, Franco, Legittimo, P.C., Iozzelli, Paolo, and Capaccioni, Bruno, 1991, 1980-1990: Ten years of geochemical investigation at Phlegrean Fields (Italy): Journal of Volcanology and Geothermal Research, v. 48, nos. 1/2, p. 161-171.

Mattox, T.N., 1993, Where lava meets the sea: Kilauea Volcano, Hawai'i: Earthquakes and Volcanoes, v. 24, no. 4, p. 160-177.

McDougall, I., 1979, Age of shield-building volcanism of Kauai and linear migration of volcanism in the Hawaiian Island chain: Earth and Planetary Science Letters, v. 46, p. 31-42.

McMurtry, G.M., Fan, Pow-Foong, and Coplen, T.B., 1977, Chemical and isotopic investigations of groundwater in potential geothermal areas in Hawaii: American Journal of Science, v. 277, p. 438-458.

Moore, R. B., and Kauahikaua, J.P., 1993, The hydrothermal-convection systems of Kilauea: An historical perspective: Geothermics, v. 22, no. 4, p. 233-241. [This issue contains three other papers on hydrothermal studies at Kilauea].

Moulds, T.N., Heliker, C., Hon, K., Kauahikaua, J., Wright, T., and Bussard, W.J., 1990, Kilauea eruption update [abstract]: Transactions, American Geophysical Union, Eos, v. 71, no. 43, p. 1694.

Murray, J.C., 1974, The geothermal system at Kilauea Volcano, Hawaii: Golden, Colorado, Colorado School of Mines, Ph.D. Dissertation (unpublished), Thesis No. T-1656, 86 pp. 
Nathenson, Manuel, and Thompson, J.M., 1990, Chemical and isotopic compositions of waters from Crater Lake, Oregon. and nearby vicinity: in Drake, E.T., Larson, G.L., Dymond, Jack, and Collier, Robert, editors, Crater Lake: An ecosystem study: Pacific Division, Amer. Assn. Advancement of Science, San Francisco, Calif., p. 91-102.

Olson, H. J., and Deymonaz, J.E., 1992, The Hawaii Scientific Observation Hole (SOH) Program Summary of Activities: Transactions, Geothermal Resources Council, v. 16, p. 47-52.

Olson, H.J., Seki, A.S., Deymonaz, J.E., and Thomas, D.M., 1990, The Scientific Observation Hole (SOH) Program: Transactions, Geothermal Resources Council, v. 14, p. 791-798.

Oskarsson, Niels, 1984, Monitoring of fumarole discharge during the 1975-1982 rifting in Krafla Volcanic Center, north Iceland: Journal of Volcanology and Geothermal Research, v. 22, no. 1/2, p. 97-121.

Peterson, D.W., and Moore, R.B., 1987, Geologic history and evolution of geologic concepts, Island of Hawaii, in Decker, R.W., Wright, T.L., and Stauffer, P.H., editors, Volcanism in Hawaii: U.S. Geological Survey Professional Paper 1350, Volume 1, Chapter 7, p. 149-189.

Plummer, L.N., Jones, B.F., and Truesdell, A.H., 1976, WATEQF-a FORTRAN IV version of WATEQ, a computer program for calculating chemical equilibrium of natural waters: U.S. Geological Survey Water Resources Investigations 76-13 (revised 1984), $70 \mathrm{p}$.

Rowan, L.R., and Clayton, R.W., 1993, The three-dimensional structure of Kilauea Volcano, Hawaii, from travel time tomography: Journal of Geophysical Research, v. 98 , p. $4355-4375$.

Rowe, G.L., Jr., Brantley,S.L., Fernandez, M., Fernandez, J.F., Borgia, A., and Barquero, J., 1992a, Fluid-volcano interaction in an active stratovolcano: The crater lake system of Poás volcano, Costa Rica: Journal of Volcanology and Geothermal Research, v. 49 , no. $1 / 2$, p. 23-51.

Rowe, G.L., Jr., Ohsawa, S., Takano, B., Brantley, S.L., Fernandez, J.F., and Barquero, J., 1992b, Using crater lake chemistry to predict volcanic activity at Poás Volcano, Costa Rica: Bulletin of Volcanology, v. 49, p. 494-503.

Scholl, M.A., Ingebritsen, S.E., Janik, C.J., and Kauahikaua, J.P., 1992, Geochemical and stable-isotope composition of precipitation and groundwater, Kilauea Volcano area, Hawaii-Preliminary results [Abstract]: Eos, Transaction American Geophysical Union, v. 73, no. 43, p. 161. 
Scholl, M.A., Janik, C.J., Ingebritsen, S.E., Kauahikaua, J.P., and Trusdell, F.A., 1993, Preliminary results from an isotope hydrology study of the Kilauea Volcano area, Hawaii: Transactions, Geothermal Resources Council, v. 17, p. 187-194.

Shupe, J.W., Helsley, C.E., and Yuen, P.C., 1978, The Hawaii geothermal project: Summary report for Phases I, II, and III: U.S. Department of Energy Report SAIV1093-T6, 22 p.

Skougstad, M.W., Fishman, N.J., Friedman, L.C., Erdmann, D.E., and Duncan, S.S., eds., 1979, Methods for determination of inorganic substances in water and fluvial sediments: Techniques of Water-Resources Investigations of the U.S. Geological Survey, Book 5, Chapter A1, 626 p.

Sturchio, N.C., Williams, S.N., Garcia P., N., and Londoño, A.C., 1988, The hydrothermal system of Nevado del Ruiz volcano, Colombia: Bulletin Volcanology, v. 50, p. 399-412.

Sudradjat, Adjat, 1991, A preliminary account of the 1990 eruption of the Kelut Volcano: Geol. Jahrbuch, v. A 127, p. 447-462.

Swain, L.A., 1973, Chemical quality of ground water in Hawaii: U.S. Geological Survey, in cooperation with the Department of Land and Natural Resources of the State of Hawaii, Report R48, $54 \mathrm{pp}$.

Takano, B., and Watanuki, K., 1990, Monitoring of volcanic eruptions at Yugama crater lake by aqueous sulfur oxyanions: Journal of Volcanology and Geothermay Research, v. 40, no. 1, p. 71-87.

Takano, Bokuichiro, 1987, Correlation of volcanic activity with sulfur oxyanion speciation in a crater lake: Science, v. 235, no. 4796, p. 1633-1635.

Thomas, D.M., 1984, Geothermal resources assessment in Hawaii-Final Report: Report DOE/SF/10819-T1, prepared for the U.S. Department of Energy by the Hawaii Institute of Geophysics, Honolulu, Hawaii, 114 p.

Thomas, D.M., Olson, H.J., and Seki, A., 1990, Stratigraphic and hydrologic observations in a continuously-cored scientific observation hole on the Kilauea east rift zone [abstract]: Transactions, American Geophysical Union, Eos, v. 71, no. 17, p. 663.

Thomas, Donald, 1987, A geochemical model of the Kilauea east rift zone, in Decker, R.W., Wright, T.L., and Stauffer, P.H., eds., Volcanism in Hawaii: U.S. Geological Survey Professional Paper 1350, volume 2, chapter 56, p. 1507-1525.

Thompson, J.M., 1990, Chemical Data from Thermal and Nonthermal Springs in Mount St. Helens National Monument, Washington: U.S. Geological Survey Open-File Report 90-690A, 16 p. 
Tilling, R.I., and Dvorak, J.J., 1993, The anatomy of an active basaltic volcano: Nature, v.363, no. 6425 , p. 125-133.

Tilling, R.I., and Jones, B.F., 1990, Temporal variations in composition of water above the magma reservoir of Kilauea Volcano, Hawaii [abstract]: Transactions, American Geophysical Union, Eos, v. 71, no. 17, p. 663.

Tilling, R.I., and Jones, B.F., 1991a, Composition of waters from the research drill hole at summit of Kilauea Volcano and of selected thermal and non-thermal groundwaters, Hawaii: U.S. Geological Survey Open-File Report 91-133-A, 27 p. [This report also available as a 3.5-inch diskette as Open-File Report 91-133-B; this version requires an Apple II or MacIntosh II, and the text and inserted graphics are in Microsoft Word, v. 4.0].

Tilling, R.I., and Jones, B.F., 1991b, Monitoring of composition of waters from the research borehole at the summit of Kilauea Volcano, Hawaii [abstract]: Abstracts Volume, International Conference on Active Volcanoes and Risk Mitigation, 27 August-1 September, 1991, Napoli, Italy, unpaginated.

Tilling, R.I., Christiansen, R.L., Duffield, W.A., Endo, E.T., Holcomb, R.T., Koyanagi, R.Y., Peterson, D.W., and Unger, J.D., 1987, The 1972-74 Mauna Ulu eruption, Kilauea Volcano, Hawaii: An example of "quasi-steady state" magma transfer, in Decker, R.W., Wright, T.L., and Stauffer, P.H., editors, Volcanism in Hawaii: U.S. Geological Survey Professional Paper 1350, Volume 1, Chapter 16 p. 405-469.

White, A.F., and Hochella, M.F., Jr., 1992, Surface chemistry associated with the cooling and subaerial weathering of recent basalt flows: Geochimica Cosmochimica Acta, v. 56, p. 3711-3721.

White, A.F., Blum, A.E., Bullen, T.D., Peterson, M.L., Schulz, J.S., and Harden, J.W., 1992, A three million year weathering record for a soil chronosequence developed in granitic alluvium, Merced, California, USA, in Kharaka, Y.K., and Maest, A.S., editors, Proceedings of the 7 th International Symposium on water-rock interaction, Park City, Utah, 13-18 July 1992: A.A. Balkema, Rotterdam, The Netherlands, v. 1, p. 607-610.

White, D.E., 1968, Hydrology, activity, and heat flow of the Steamboat Springs thermal system, Washoe County, Nevada: U.S. Geological Survey Professional Paper 458C, $109 \mathrm{p}$.

White, D.E., Hem, J.D., and Waring, G.A., 1963, Chemical composition of subsurface waters, in Fleischer, Michael, tech. ed., Data of Geochemistry, Sixth Edition: U.S. Geological Survey Professional Paper 440-F, p. F1-F67. 
Wilson, T.J., 1963, A possible origin of the Hawaiian Islands: Canadian Journal of Physics, v. 41, p. 863-870.

Wolfe, E.W., editor, 1988, The Puu Oo eruption of Kilauea Volcano, Hawaii: Episodes 1 through 20, January 3, 1983, through June 8, 1984: U.S. Geological Survey Professional Paper 1463, $251 \mathrm{p}$.

Wood, W.W., and Fernandez, L.A., 1988, Volcanic rocks, in Back, W., Rosenshein, J.S., and Seaber, P.R., eds., Hydrogeology: Boulder, Colorado, Geological Society of America, The Geology of North America, v. O-2, Chapter 39, p. 353365.

Zablocki, C.J., Tilling, R.I., Peterson, D.W., Christiansen, R.L., and Keller, G.V., 1976, A deep research drill hole at Kilauea Volcano, Hawaii: U.S. Geological Survey Open-File Report 76-538, 35 p.

Zablocki, C.J., Tilling, R.I., Peterson, D.W., Christiansen, R.L., Keller, G.V., and Murray, J.C., 1974, A deep research drill hole at the summit of an active volcano, Kilauea, Hawaii: Geophysical Research Letters, v. 1, no. 7, p. 323-326.

Zielinski, R.A., Lipman, P.W., and Millard, H.T., Jr., 1977, Minor-element abundances in obsidian, perlite, and felsite of calc-alkalic rhyolites: American Mineralogist, v. 62 , nos. 5-6, p. 426-437. 


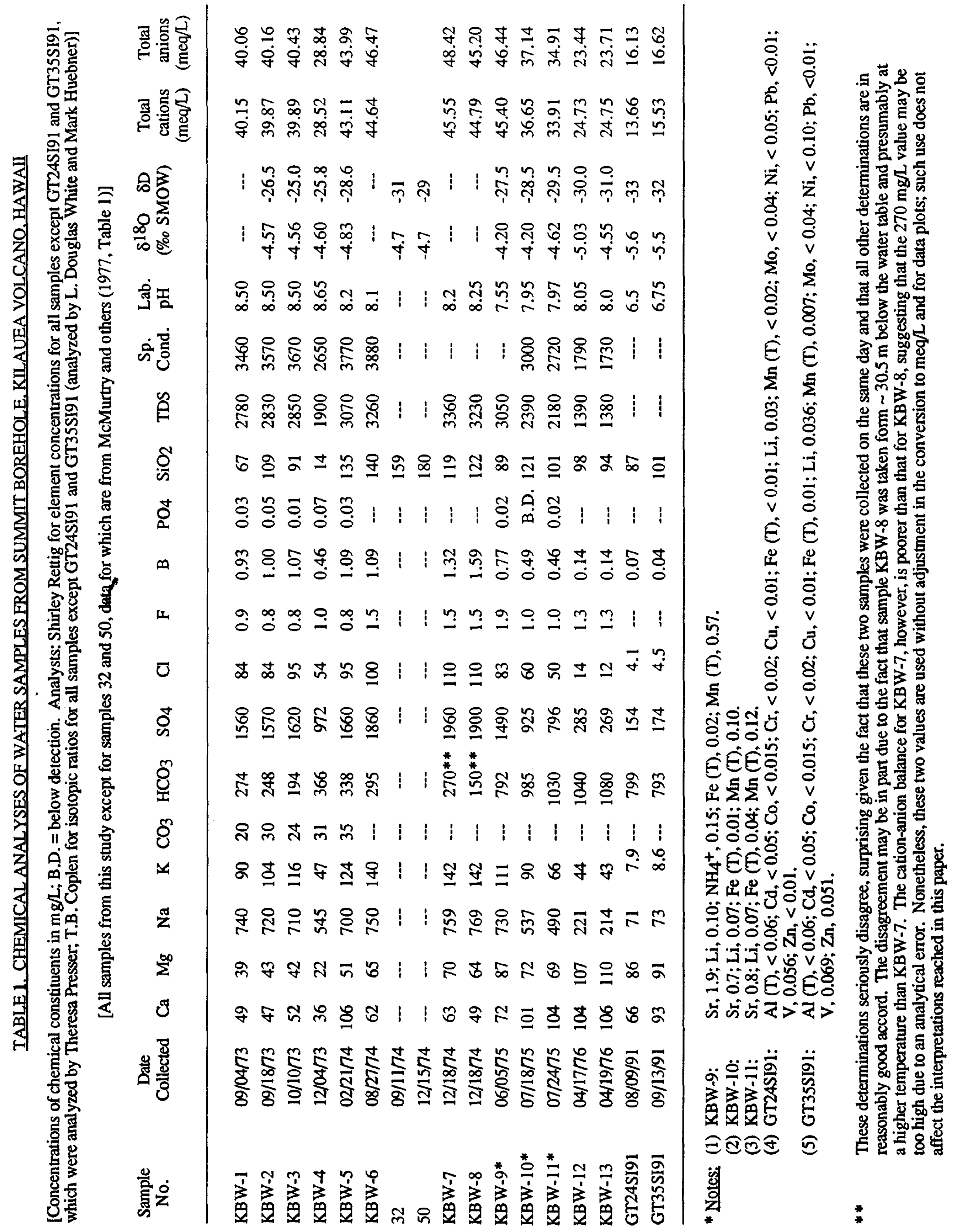




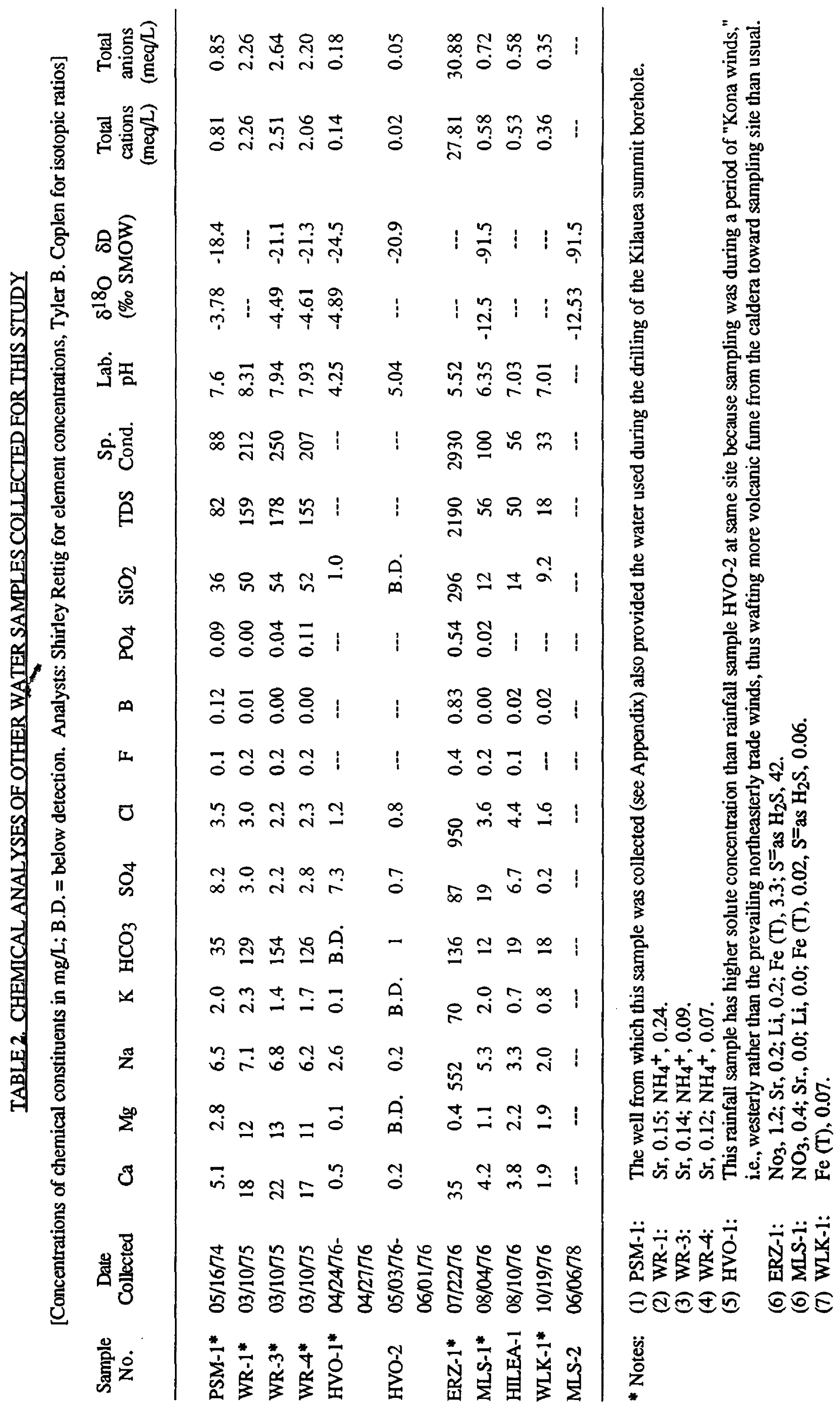




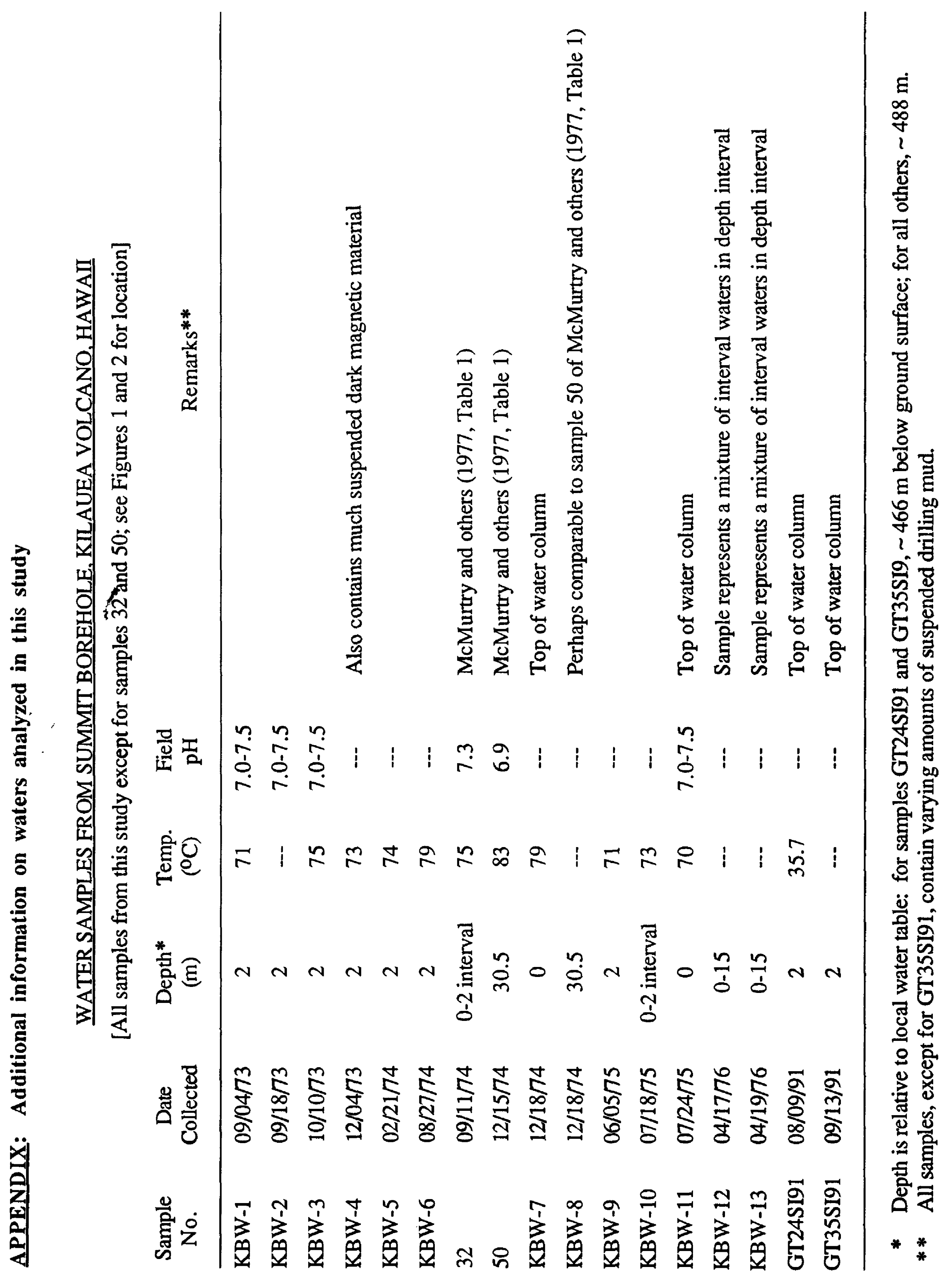




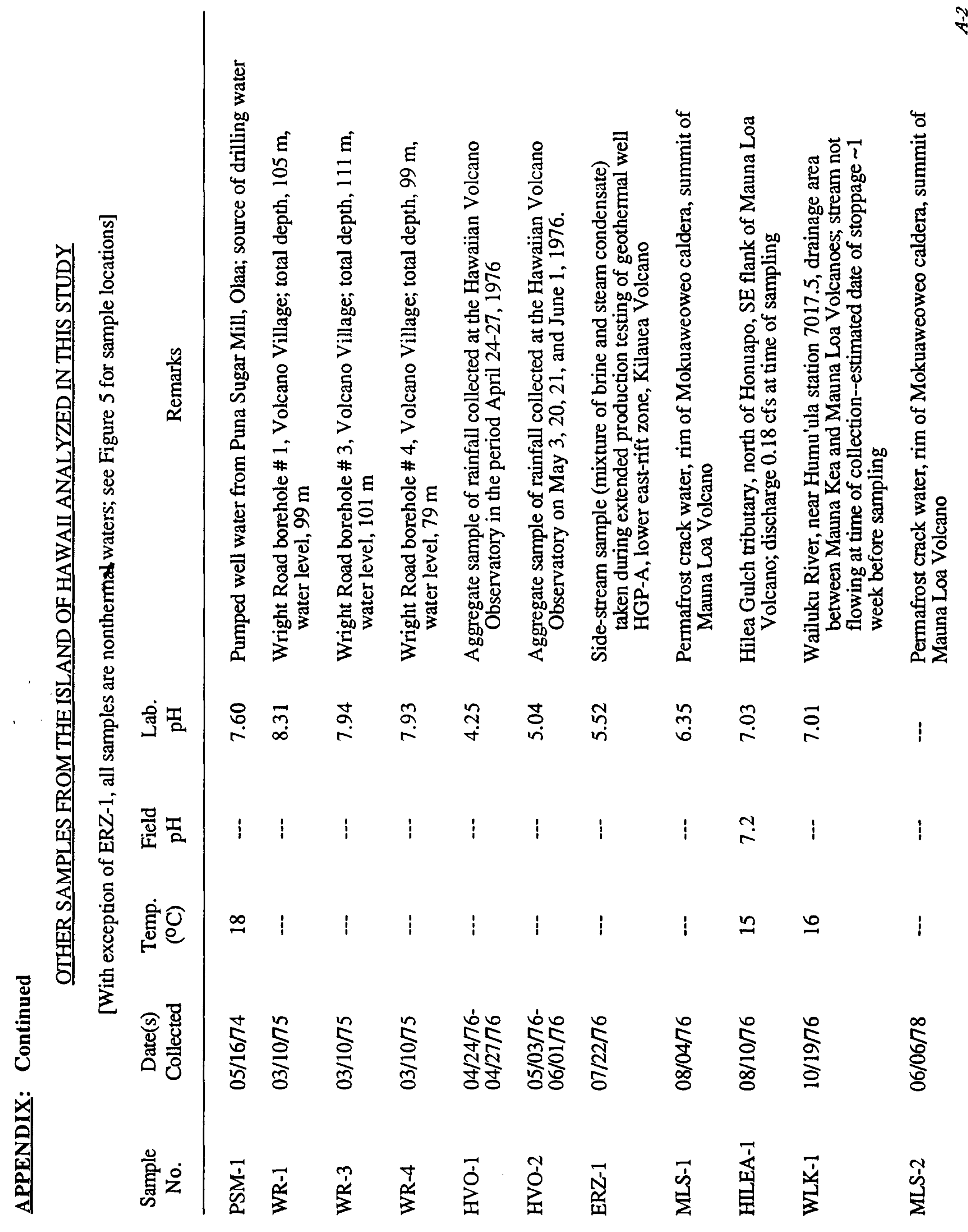

